\title{
Influence of sediment composition on PAH toxicity using zebrafish (Danio rerio) and Japanese medaka (Oryzias latipes) embryo-larval assays
}

\author{
Perrichon Prescilla ${ }^{1,2,{ }^{*}}$, Le Bihanic Florane ${ }^{3}$, Bustamante Paco ${ }^{2}$, Le Menach Karyn ${ }^{3}$, \\ Budzinski Helene ${ }^{3}$, Cachot Jerome ${ }^{3}$, Cousin Xavier ${ }^{1,4}$
}

${ }^{1}$ IFREMER, Lab Ecotoxicol, F-17137 Lhoumeau, France.

${ }^{2}$ Univ La Rochelle, CNRS, Littoral Environm \& Soc LIENSs, UMRi 7266, F-17042 La Rochelle 01, France.

${ }^{3}$ Univ Bordeaux, UMR CNRS 5805, EPOC, F-33405 Talence, France.

${ }^{4}$ INRA, LPGP, F-35042 Rennes, France.

* Corresponding author : Prescilla Perrichon, email address : prescilla.perrichon@hotmail.fr

\begin{abstract}
:
Due to hydrophobic and persistent properties, polycyclic aromatic hydrocarbons (PAHs) have a high capacity to accumulate in sediment. Sediment quality criteria, for the assessment of habitat quality and risk for aquatic life, include understanding the fate and effects of PAHs. In the context of European regulation (REACH and Water Framework Directive), the first objective was to assess the influence of sediment composition on the toxicity of two model PAHs, benzo[a]pyrene and fluoranthene using 10day zebrafish embryo-larval assay. This procedure was undertaken with an artificial sediment in order to limit natural sediment variability. A suitable sediment composition might be then validated for zebrafish and proposed in a new OECD guideline for chemicals testing. Second, a comparative study of toxicity responses from this exposure protocol was then performed using another OECD species, the Japanese medaka. The potential toxicity of both PAHs was assessed through lethal (e.g., survival, hatching success) and sublethal endpoints (e.g., abnormalities, PMR, and EROD) measured at different developmental stages, adapted to the embryonic development time of both species. Regarding effects observed for both species, a suitable artificial sediment composition for PAH toxicity testing was set at $92.5 \%$ dry weight $(\mathrm{dw})$ silica of $0.2-0.5-\mathrm{mm}$ grain size, $5 \% \mathrm{dw}$ kaolin clay without organic matter for zebrafish, and $2.5 \%$ dw blond peat in more only for Japanese medaka. PAH bioavailability and toxicity were highly dependent on the fraction of organic matter in sediment and of the $\mathrm{K}$ (ow) coefficients of the tested compounds. The biological responses observed were also dependent of the species under consideration. Japanese medaka embryos appeared more robust than zebrafish embryos for understanding the toxicity of PAHs following a sediment contact test, due to the longer exposure duration and lower sensitivity of sediment physical properties.
\end{abstract}


Keywords: Fish embryo-larval assay, PAHs, Artificial sediment, EROD, Behavioral performance, Teratogenicity

\section{Abbreviations}

AhR Aryl hydrocarbon receptor

$\mathrm{PAH}$ Polycyclic aromatic hydrocarbon

BaP Benzo[a]pyrene

Fluo Fluoranthene

Hpf Hours post-fertilization

Dpf Days post-fertilization

EROD Ethoxyresorufin-O-deethylase

PMR Photomotor response 


\section{Introduction}

The aquatic environment continuously receives anthropogenic pollutants which impact the habitat quality of these ecosystems and can represent an important threat for aquatic life. Natural phenomena - tides, storms and bioturbation - (Hollert et al. 2000) and anthropogenic activities - trawling, dredging and wake waves - (Köthe 2003) can release sediment-linked pollutants such as Polycyclic Aromatic Hydrocarbons (PAHs) into the water column, leading to acute exposure of aquatic organisms. PAHs constitute an important part of pervasive compounds and their emission is increasing with the development of human activities (van der Oost et al. 2003; Shen et al. 2013). The PAH persistence, behavior and distribution in the environment are mediated by their physico-chemical properties (aromaticity and molecular weight). Indeed, the presence of a high number of aromatic rings (=PAH of high molecular weight) dictates their strong hydrophobicity, while their solubility and volatility are reduced (Dabestani and Ivanov 1999). Due to these hydrophobic properties, most PAHs have a high capacity to sorb on particles and favor their accumulation in sediments which can result in high PAH concentrations in aquatic ecosystems. In Europe, PAH concentrations into the sediment can reach up to $50 \mu \mathrm{g} . \mathrm{g}^{-1}$ dry weight (dw) in area relatively contaminated (Baumard et al. 1999; Benlahcen et al. 1997; Cachot et al. 2006; El Nemr et al. 2007). Sediments are therefore recognized to be a major source of contamination, causing a threat to organisms for which they are habitat and a food source (Ahlf et al. 2002; Wölz et al. 2009). Toxicity assessment of the PAHs is necessary to determine sediment quality values in order to assess their impact on aquatic life. PAHs are present into the environment as mixture of sole PAH and often associated with others chemicals (metallic and/or organic). The exposure to these PAHs leads to a variety of effects in aquatic organisms. They can bind to the Aryl hydrocarbon Receptor (AhR) and subsequently induce the synthesis of cytochrome P4501A (CYP1A) (specially for the AhR agonists-PAH). The induction of CYP1A is commonly measured through the phase I biotransformation activity, ethoxyresorufin-O-deethylase (EROD) activity. The activation of these mechanisms (not necessarily related to the AhR), modulate a battery of genes involved in metabolism impacting negatively exposed-organisms at different biological level (Meador et al. 1995; van der Oost et al. 2003). PAHs are well-described in literature for their genotoxic, mutagenic and carcinogenic mode of action (Larcher et al. 2014; Patel et al. 2006; Wessel et al. 2010). They can also decrease the development, the growth and morphology, which alter the survival and population recruitment of aquatic organisms (Heintz et al. 2000; Incardona et al. 2011; Kerambrun et al. 2012; Scott et al. 2011). In recent decades, a number of different ecotoxicity tests have been developed for risk assessment of industrial chemicals. However, the extensive use of these tests raises ethical concerns, in terms of the use of live animal and the degree of induced-pain and -suffering. In application of the 3Rs principle (Replace, Reduce and Refine), established by Russell and Burch (1959), and the REACH regulation (Registration, Evaluation, Authorization \& Restriction of Chemicals) (Hengstler et al. 2006; Van der Jagt et al. 2004), appropriate methods need to be 
2009; Scholz et al. 2013; Strähle et al. 2012). Taking into consideration the regulatory policy of animal welfare, the last thirty years have seen the development of in vitro ecotoxicity assays and moves to promote testing of primary cell cultures or fish cell lines. Although these assays are fast, reduce the equipment requirement and limit the use of live animals, they are not completely transposable to the natural environment quality assessment. These assays can lead to a high variability of responses depending on the physiological status of donor fish and/or the preparation quality of the procedure (Castaño et al. 2003). The use of fish embryo-larval stages - as an experimental model - is one of the robust alternative methods proposed for chemical testing; mixing benefits of both in vivo (metabolism and relevance point of view) and in vitro models (experimental cost and model sensitivity point of view). These life stages (from the embryonic stage until the onset of exogenous feeding) are not also covered by the EU directive on the protection of animals used for scientific purposes (2010/63/EU). Five main species have been recommended for chemical risk assessment: bluegill (Lepomis macrochirus), fathead minnow (Pimephales promelas), rainbow trout (Oncorhyncus mykiss), zebrafish (Danio rerio) and Japanese medaka (Oryzias latipes) (Lammer et al., 2009; OECD 2013a; 1998). In the present study, zebrafish and Japanese medaka were selected as experimental models. The use of zebrafish for toxicity testing offers multiple benefits (Hill et al. 2005; Spitsbergen and Kent 2003). First, they are easily bred in the laboratory and eggs are available in high numbers throughout the year. Second, transparency of both chorion and larvae allow at monitoring the morphological defects and at following all stages of development during exposure, which are well described and illustrated in the literature (Kimmel et al. 1995). Finally, zebrafish have a short embryonic development time (hatching between 48 and 72 hours post-fertilization (hpf) at $28{ }^{\circ} \mathrm{C}$ ). Japanese medaka offers similar advantages to zebrafish embryos, except that the embryonic development time is longer (10 to 11 days post-fertilization (dpf) at $26^{\circ} \mathrm{C}$ ). This difference in development time means that medaka have an exposure duration which is longer than zebrafish. Zebrafish and Japanese medaka have shown reliable results in toxicity assessment using aqueous exposure (Fallahtafti et al. 2012; Fang et al. 2013; Hawliczek et al. 2012; Huang et al. 2012; Incardona et al. 2011). In the case of hydrophobic compounds, direct waterborne exposure is not suitable and therefore alternative tests had to be developed. This was achieved by exposing zebrafish and medaka embryos to natural sediment and spiked sediment (Barjhoux et al. 2012; ; Hollert et al. 2003; Höss et al. 2010; Kosmehl et al. 2006; Vicquelin et al. 2011). However, the toxic effects of PAHs are not easily transposable from one study to another due to the natural sediment composition variability (seasonal variability, sampling field, experimental variability), which play a fundamental role in the bioavailability of compounds. To cope with such problems, the use of artificial sediment provides some benefits compared to natural sediment and could be a possible solution to standardize sediment exposure protocols: i) absence of background contamination, ii) wellcharacterized composition, iii) reproducible composition of sediment over time, and iv) absence of indigenous biota (Burton 2002). In fact, one artificial sediment composition was standardized by the test guideline 218 of OECD (OECD 2004) for the toxicity test using freshwater dipteran Chironomus sp.. However, its composition is not suitable for fish embryo-larval assays because it contains a high clay concentration (20\% dw) which may clog chorion pore canals of egg by fine particles, reducing oxygen exchange and optimal embryos development. In this context, the present study aimed to evaluate the influence of PAH-contaminated sediment composition on the zebrafish early life stages. First, a screening procedure with artificial sediment reference proposed for the 14day medaka embryo-larval assays (Le Bihanic et al. 2014b) was used in order to evaluate the influence of different organic matter content on the toxicity of prototypic hydrophobic molecules, the pentacyclic PAH 
benzo[a]pyrene (BaP) and the 3-benzenic-ring PAH fluoranthene (Fluo) on zebrafish embryos and larvae. This objective will permit also to validate an artificial sediment composition for zebrafish for further research. These two PAHs, listed as priority substances by the European Water Framework Directive 2000/60/EC (EC 2000), were selected for its high adsorption capacities on particles and organic matter, because their effects on fish development were demonstrated (Wassenberg and Di Giulio 2004) and they are common present in contaminated sites (Cachot et al. 2006). Exposures were performed using a procedure adapted from Le Bihanic et al. (2014) for the 10-day embryo-larval toxicity assay (including 96 hours of exposure, embryos and prolarvae) with zebrafish (OECD 2013b; 1998). Toxic responses of exposed-embryos and larvae (from the newly fertilized egg to the end of the sac-fry stages) to both of these PAHs were examined through individual, morphological and behavioral endpoints during and post-exposure, for different sediment compositions. In addition, the induction of cytochrome P4501A (CYP1A) of Aryl hydrocarbon Receptor (AhR) agonist PAH was measured by the level of ethoxyresorufin- $O$-deethylase (EROD) activity in fish. The second step consisted in the comparison of the response sensitivity (threshold and intensity) of zebrafish (96-120 hpf) and Japanese medaka (10-14 dpf) embryos and larvae for different sediment compositions, using results from this study and previously published research (Le Bihanic et al. 2014b).

\section{Materials and methods}

\subsection{Chemicals}

Benzo[a]pyrene (CAS No. 50-32-8), fluoranthene (CAS No. 206-44-0) and benzocaine (CAS No. 94-09-7) were purchased from Sigma-Aldrich (St Quentin Fallavier, France). Spiking PAH solutions were made in isooctane (CAS No. 540-84-1, HPLC grade, Scharlau Barcelona, Spain) at $750 \mu \mathrm{g} . \mathrm{L}^{-1}$. PAH spiked-sediment and chemical analysis were performed with dichloromethane (CAS No. 75-09-2) solvent from Biosolve (Valkensward, The Netherlands) and Acros Organics (Thermo Fisher Scientific, Geel, Belgium).

\subsection{Preparation of spiked artificial sediment}

The artificial sediment was prepared according to Le Bihanic et al. (2014). The reconstituted sediment was composed of sand measuring 0.2-0.5 mm (sieved from sand BB 0.2/2 h, Mios, France), $5 \%$ kaolin clay (Merck, Darmstadt, Germany) and Sphagnum blond peat (Florentaise, St Mars du Désert, France). Three concentrations of peat $(0,2.5$ and $5 \%)$ were also used to evaluate their suitability for the zebrafish embryo-larval assay. Briefly, peat was dried $48 \mathrm{~h}$ and sieved $(0.5 \mathrm{~mm})$. Milli-Q water was added to the peat $(12: 1, \mathrm{v} / \mathrm{v})$ in glass bottles and shaken for $48 \mathrm{~h}$ at $180 \mathrm{rpm}$ at room temperature. Sand and $5 \%$ kaolin clay were then mixed to humid peat, and shaken for $24 \mathrm{~h}$. pH was adjusted to 6.5 with $10 \% \mathrm{CaCO}_{3}$ solution. After seven days of stabilization (at room temperature) $1: 4 \mathrm{v} / \mathrm{v}$ of milli-Q water was added to the sediment. After a $24 \mathrm{~h}$ equilibration period, supernatant water was removed and the sediment was dried at $105^{\circ} \mathrm{C}$ for $14 \mathrm{~h}$. After cooling, the artificial sediment was spiked with two PAHs, BaP $\left(\log \mathrm{K}_{\mathrm{ow}}=6.04\right)$ and Fluo $\left(\log \mathrm{K}_{\mathrm{ow}}=5.16\right)$ at $10 \mu \mathrm{g} \cdot \mathrm{g}^{-1} \mathrm{dw}$ sediment each, equivalent to 20-fold the environmental concentration based on the concentration measured in sediments from the upper Seine estuary (France) (Cachot et al. 2006). $60 \mathrm{~mL}$ of dichloromethane and PAH solution were mixed to $30 \mathrm{~g}$ of 
sediment in a $250 \mathrm{~mL}$ round-bottom glass flask. Then, solvent was evaporated with a rotary evaporator Rotavapor (IKA, Staufen, Germany) for $60 \mathrm{~min}\left(115 \mathrm{rpm}, 45^{\circ} \mathrm{C}\right)$. The spiked sediment was stored overnight in the dark at room temperature under a fume hood to ensure complete residual solvent elimination. A solvent control sediment (dichloromethane without PAH) was prepared in the same manner. An aliquot (5 g) of each spiked sediment was sampled for PAH chemical analysis.

\subsection{PAH chemical analysis of artificial sediment}

Sediment samples (a single sample per condition) were stored at $-20{ }^{\circ} \mathrm{C}$ before chemical analysis. Fluoranthene$\mathrm{d} 10$ and benzo[a]pyrene-d12 were used as internal deuterated standards for the quantification of PAHs. Briefly, organic compounds were extracted from $0.2 \mathrm{~g}$ of sediment using a microwave (10 min at $30 \mathrm{~W}$ ) with dichloromethane (solvent) (Budzinski et al. 2000). Samples were then concentrated into $300 \mu \mathrm{L}$ of isooctane using a Vacuum Evaporation System (Rapidvap Labconco, Kansas city, USA). Extracts were purified and fractionated on alumina and silica micro-columns, following the procedure described by Behar et al. (1989). Finally, these extracts were concentrated once more in isooctane and analyzed by gas chromatography coupled to mass spectrometry (GC/MS) as described by Baumard et al. (1998). Extraction efficiencies were equivalent on average to $84 \%$.

\subsection{Zebrafish embryo-larval assays}

Maintenance and egg production of zebrafish: wild type TU strain (Tübingen, Germany) zebrafish (Danio rerio) were maintained in communities in $10 \mathrm{~L}$ tanks under standard conditions in water obtained after a mix of reverse osmosis treated water and tap water, both being filtered beforehand with dust and charcoal filters, to obtain a $\mathrm{pH}$ of $7.5 \pm 0.5$ and a conductivity of $300 \pm 50 \mu \mathrm{S} . \mathrm{cm}^{-1}$. Racks aeration allowed an oxygen saturation $\geq 80 \%$. Water and room temperature were kept between 26 and $28{ }^{\circ} \mathrm{C}$ with a14 h light/10 h dark photoperiod. Ammonia, nitrite and nitrate were monitored daily for 2 months then weekly and remained within recommended ranges (Lawrence 2007). The fish were fed twice a day with commercial granulates (INICIO Plus 0.5, BioMar, France) and an additional distribution of Artemias sp. nauplii (INVE, Belgium), occasionally supplemented with red sludge worms (Boschetto-Frozen fish food). Eggs were obtained by random pairwise mating of zebrafish. One adult male and one female were placed together in spawning boxes (AquaSchwarz, Germany) the evening before eggs were required. Spawning and fertilization took place within $30 \mathrm{~min}$ after the onset of light in the morning.

Zebrafish exposure (Fig. 1 Supplementary data): Two consecutive experiments were done, the first with BaP and second one with Fluo compound. Fertilized and normally developed eggs were selected at 8-cell stage (1h15 post-fertilization) using a dissecting microscope. The egg fertilization rate had to be $\geq 70 \%$ and a mix of five spawns was used to avoid a potential spawn effect. Artificial water (E3) according to ISO 7346/3 (1996) was used as test medium $\left(0.33 \mathrm{mM} \mathrm{CaCl} 2,0.33 \mathrm{mM} \mathrm{MgSO}_{4}, 5 \mathrm{mM} \mathrm{NaCl}\right.$ and $\left.0.17 \mathrm{mM} \mathrm{KCl}\right)$. Exposure tests were carried out in plastic petri dish ( $35 \mathrm{~mm}$ diameter) with $3 \mathrm{~g} \mathrm{dw}$ artificial sediment and $3 \mathrm{~mL}$ artificial water in triplicates as reported by Daouk (2011) and Vicquelin et al. (2011). 30 embryos were placed randomly on a 1 $\mathrm{mm}$ thermoformed Nytex ${ }^{\circledR}$ grid to avoid being buried in the sediment, and exposed for 96 hours in incubator at 
$28 \pm 0.5^{\circ} \mathrm{C}$, with the same photoperiod as the rearing room. During exposure, petri dishes were covered with a lid in order to prevent evaporation. At the end of exposure, larvae were transferred to new petri dishes containing only freshly-prepared E3 medium ( $30 \mathrm{~mL}$ ) until $10 \mathrm{dpf}$ for analysis. Larvae were not fed during the experiment.

Survival and hatching success: Embryonic and larvae survival were recorded daily until $10 \mathrm{dpf}$. Dead individuals were removed. The survival rate (SR) was estimated as: $\mathrm{SR}=100 *\left(\mathrm{SNt}_{\mathrm{x}} / \mathrm{SNt}_{0}\right)$, where $\mathrm{SNt}_{\mathrm{x}}$ and $\mathrm{SNt}_{0}$ are the number of live individuals at times $\mathrm{t}_{\mathrm{x}}$ (time of the measure, hpf) and $\mathrm{t}_{0}$ (beginning of the experiment, $0 \mathrm{hpf}$ ). Similarly, hatched individuals were counted between 48 and $72 \mathrm{hpf}$. At the end of exposure (96 hpf), hatching success (HS) was calculated as: $\mathrm{HS}=100 *\left(\mathrm{HIt}_{96 \mathrm{~h}} / \mathrm{SNt}_{96 \mathrm{~h}}\right)$, where $\mathrm{HIt}_{96 \mathrm{~h}}$ is the number of hatched and living larvae. SR and HS were expressed as percentages.

Biometric measurements and abnormalities monitoring: At the end of exposure (96 hpf), larvae (35-39 per condition) were anesthetized with benzocaine $\left(16 \mu \mathrm{g} \cdot \mathrm{L}^{-1}\right)$. Larvae were immobilized in left lateral view with $3 \%$ methylcellulose gel (dissolved in E3 medium) under dissecting microscope (Olympus SZX9, 10x). Then, larvae were photographed using a DMK 31AU03 camera and IC Capture 2.2 software (both The Imaging Sources, Germany). From these pictures, head length (from terminal point of lower jaw to rear operculum), standard body length (from terminal point of lower jaw to the end of tail without caudal fin) and yolk sac area (including swim bladder area) were measured with ImageJ software (Schneider et al. 2012). Furthermore, morphological abnormalities were recorded individually based on the sublethal endpoints as described in Lammer et al. (2009). Abnormalities scored were: 1- Oedema formation (brain, pericardia, yolk sac); 2- Skeletal deformities (scoliosis, lordosis, tail bud deformities); 3- Craniofacial deformities (jaw, development of eyes, head deformities); 4Cardiac deformities (anemia, hemorrhage, atrium/ventricle size, blood circulation heart position); 5- Yolk sac malabsorption. Abnormalities were analyzed with a scoring system from 0 to 3 according to their occurrence and severity: (0) healthy larvae, (1) one abnormality or mildly-affected, (2) two abnormalities or moderately affected and (3) three or more abnormalities or severely affected larvae. In addition, general developmental retardation was noted, when the larvae development was delayed (time point of view) compare to normal development. Results were expressed as a percentage of all surviving larvae.

Behavioral test by monitoring of PhotoMotor Response: behavioral tests were conducted to monitor photomotor response (PMR), following the procedure described by Péan et al. (2013) with slight modifications. The day before analysis, $4 \mathrm{dpf}$ larvae were acclimated individually in a 24 well-plate (Krystal 24, transparent bottom and opaque walls) with $2 \mathrm{~mL}$ of E3 medium in a climate chamber $\left(28 \pm 0.5^{\circ} \mathrm{C} ; 14 \mathrm{~h}\right.$ light $/ 10 \mathrm{~h}$ dark photoperiod). Well-plates were covered with a lid to avoid evaporation and were transferred two hours before video tracking in an analysis room $\left(28 \pm 0.5{ }^{\circ} \mathrm{C}\right.$ in light) the following day to perform behavioral analysis. Behavioral analyses were performed during a period of stable activity (between 1 and $6 \mathrm{pm}$ ) for zebrafish according to MacPhail et al. (2009). Larvae were filmed in a lightproof and temperature-controlled box with a DMK31AU03 camera (The Imaging Sources, Germany) and lens Fujinon (1.4-12.5 mm) and IC Capture 2.2 software (The Imaging Sources, Germany). An infrared floor in the box was used to record in both light and dark conditions. Larvae were placed in the box five minutes before recording their behavior in order to acclimatize them to light. Recording covered three periods: $5 \mathrm{~min}$ light on (1), 5 min light off and 5 min light on (2). Video analyses were performed with 
Ethovision 8.5 software (Noldus, The Netherlands). The behavioral performances of larvae (30 per PAH treatments) were assessed by measuring the distance moved $(\mathrm{cm})$ during the three periods of the light/dark/light challenge. The distance moved is calculated by the difference between the center point of the larvae from two consecutive $\mathrm{X}-\mathrm{Y}$ coordinates summed over a 5 -min period.

In vivo EROD activity: the CYP1A activation was measured via the EROD activity analysis, according to the in vivo assays of Carney et al. (2004) and Otte et al. (2010) with slight modifications. Briefly, CYP1A metabolism converts ethoxyresorufin to resorufin, which was observed and quantified in the gastrointestinal cavity of $96 \mathrm{hpf}$ larvae via fluorescence microscopy. Individual larvae (15 larvae per treatment) from each replicate treatment were incubated in $21 \mu \mathrm{g} . \mathrm{L}^{-1}$ 7-ethoxyresorufin (Sigma-Aldrich, St Quentin Fallavier, France) dissolved in $1 \mathrm{~mL}$ of E3 for 5 hours. Larvae were then anesthetized with $16 \mu \mathrm{g} . \mathrm{L}^{-1}$ benzocaine and mounted in $3 \%$ methylcellulose to immobilize them (left lateral view) for observation of the yolk sac. The entire procedure was performed in light-protected conditions and at $28 \pm 0.5{ }^{\circ} \mathrm{C}$. Fluorescence of the resorufin was examined under a fluorescence microscope (Olympus BX41, 100x) equipped with a Rhodamin red filter (excitation/emission: $560 \mathrm{~nm} / 580 \mathrm{~nm}$ ). The yolk sac of larvae was photographed with a camera (DMK31AU03) and IC Capture 2.2 software (both The Imaging Sources, Germany). Image analysis was done with HeatMap Histogram plugin (Péan S., http://www.samuelpean.com/heatmap-histogram/) from ImageJ software (Schneider et al. 2012). For EROD analysis, a control treatment composed of 15 non-sediment exposed larvae was analyzed in addition to establish the background. Results were expressed in integrated density of pixels (arbitrary unit).

\subsection{Medaka embryo-larval assay}

Japanese medaka exposure (Fig.1 Supplementary data): The fish embryo-larval toxicity test was performed as described in Le Bihanic et al. (2014). The BaP and Fluo exposures were performed in same time and with the same batch of eggs. 1 dpf medaka embryos (CAB strain providing GIS-Amagen (INRA), Jouy-en-Josas, France) were exposed using the same procedure as for zebrafish embryos with some modifications adapted to the longer embryonic development time. Embryos were exposed throughout embryonic development until the hatching peak (11 dpf) at $26 \pm 0.3{ }^{\circ} \mathrm{C}$ with a $12 \mathrm{~h}$ light $/ 12 \mathrm{~h}$ dark photoperiod. During the exposure, artificial water was renewed daily. Egg Rearing Solution ERS was used as artificial water $(85.6 \mathrm{mM} \mathrm{NaCl}, 0.4 \mathrm{mM} \mathrm{KCl}, 0.4 \mathrm{mM}$ $\mathrm{CaCl}_{2}$ and $1.4 \mathrm{mM} \mathrm{MgSO}_{4}$ ). After hatching, larvae were observed and transferred to a new petri dish containing a mix of osmose water and tap water. The experiment was halted three days post hatching peak.

Behavioral test by monitoring of PMR: PMRs were measured in similar conditions to zebrafish assay with slight adaptations for Japanese medaka. 14 dpf larvae were acclimated individually for 2 hours in a 48 well-plate with $500 \mu \mathrm{l}$ of ERS in the dark inside the Daniovision chamber (Noldus, The Netherlands) at $23{ }^{\circ} \mathrm{C} .15$ larvae per treatment were filmed with an IR digital video camera (Ikegami Electronics, Neuss, Germany) during four periods of $10 \mathrm{~min}$ : $10 \mathrm{~min}$ light off (1), $10 \mathrm{~min}$ light on (1), $10 \mathrm{~min}$ light off (2) and $10 \mathrm{~min}$ light on (2). The analysis time was increased, and a dark period was added at the start of the challenge due to the higher swimming activity in medaka compared to zebrafish. This supplementary phase enabled their swimming to be stabilized so as not to skew the challenge. The video analyses were then performed with Ethovision 9.0 software 
(Noldus, The Netherlands). As for zebrafish assay, the behavioral performances of larvae were assessed by measuring the distance moved $(\mathrm{cm})$ during the four periods of the dark/light/dark/light challenge.

\subsection{Statistical analysis}

Statistical analyses were performed using Statistica 9.0 software (StatSoft, USA). A one-way ANOVA was conducted for each variable and treatment to assess differences between experimental replicates. If no difference between replicates was detected, the three replicates were considered as a homogenous group. Normality and homoscedasticity of the data were verified using Shapiro-Wilk and Levene tests respectively. For percent survival, hatching and abnormalities data, Fisher tests were performed. Student's $t$ tests were performed for the biometric analysis and the PMR in order to assess the effects of the different exposure treatment (BaP, Fluo) with their respective solvent control. EROD data were analyzed using a one-way ANOVA supplemented by a post-hoc Tukey test. When the parametric assumptions were not respected, the non-parametric Mann-Whitney and Kruskal-Wallis tests were conducted. The behavioral data for Japanese medaka assay were analyzed with an ANOVA. Results were expressed as mean \pm SEM. The statistical significance threshold was fixed at $\mathrm{p}=0.05$.

\section{Results}

\subsection{Chemical analysis of spiked sediments}

Spiking efficiencies of PAH on sediment ranged from 17 to $63 \%$ depending on peat concentrations and the compound analyzed (Table 1). For BaP, they were of 17, 18 and $20 \%$ for $0,2.5$ and $5 \%$ peat conditions respectively. Fluo spiking efficiency was slightly higher for no-peat sediment (63\%) than for $2.5 \%$ (59 \%) and $5 \%$ peat $(44 \%)$.

\subsection{Zebrafish embryo-larval assay}

Survival and hatching success: the survival and hatching success of zebrafish embryos during $\mathrm{BaP}$ and Fluo exposures are shown in Table 1. Whatever the peat proportion, the BaP tested concentration did not induce lethal effects on embryos and larvae, while that was the case for the Fluo exposure. The survival rate for BaP-exposed fish ranged from 89.9 to $95.6 \%$ at the end of the exposure (96 hpf) and from 88.9 to $92.2 \%$ at $10 \mathrm{dpf}$. In contrast, $0 \%$ and $5 \%$ Fluo-spiked sediments induced a significant decrease in survival compared to the solvent control group with $54.6 \%$ and $83.5 \%$ respectively (Fisher, $\mathrm{p}<0.01$ ). For $2.5 \%$ peat Fluo-spiked sediment, no significant larval mortality was observed with $95.6 \%$ and $96.7 \%$ for the solvent and Fluo survival rate respectively (Fisher, $\mathrm{p}>0.05$ ).

$\mathrm{BaP}$ did not induce a hatching delay for all three sediment peat contents (success varied from 95.2 to $100 \%$ ). In contrast, hatching success was significantly reduced by Fluo in 0 and $5 \%$ peat sediment as compared to respective control group (decreasing of $10.4 \%$ and $13.5 \%, p=0.005$ and $p=0.004$ respectively). 
Biometric measurements: biometric measurements of 96 hpf larvae exposed to BaP or Fluo for each peat content are shown in Tables 2 and 3, respectively. BaP exposure did not induce modifications of larval biometric parameters whatever the sediment peat contents (Table 2). For $0 \%$ peat content (Table 3), standard body length and ratio head/standard length were significantly reduced in Fluo-exposed larvae (1.1 fold smaller as compared to control larvae, Student's $t, p<0.001$ each). In contrast the yolk sac area and yolk sac/whole larval area ratio were significantly increased by 1.3 and 1.4 fold respectively (Student's t, $\mathrm{p}<0.001$ ). For $2.5 \%$ peat content, no biometric modifications were observed between treatments except for the yolk/whole larval area ratio in Fluoexposed larvae ( 1.04 fold) that were significantly increased (Student's $t, p=0.04)$. In the case of $5 \%$ peat content, larvae exposed to Fluo had a yolk sac/whole larval area ratio 1.1 fold larger than control larvae (Student's t, $\mathrm{p}=0.04$ ). These larvae also showed a significant reduction in standard body length (Student's t, $\mathrm{p}=0.004$ ).

Morphological abnormalities: the percentage of abnormal individuals at $96 \mathrm{hpf}$, and the different abnormalities and severity are also summarized in Tables 2 and 3 for BaP for Fluo treatments, respectively. Peat concentration in each treatment did not induce significant morphological abnormalities compared to the respective control (Fisher, $\mathrm{p}=0.61, \mathrm{p}=0.73$ and $\mathrm{p}=1.0$ for $0 \%, 2.5 \%$ and $5 \%$ respectively). No developmental time retardation was observed in BaP exposed larvae whatever the peat concentration. In the absence of peat, $56 \%$ of Fluo-exposed larvae exhibited a delayed development time and $100 \%$ of larvae at the highest peat concentration. $49 \%$ of larvae solvent of the control exposed to sediment with $5 \%$ peat concentration was also retarded time point of view.

In vivo EROD activity: EROD activities in $96 \mathrm{hpf}$ zebrafish larvae exposed to $\mathrm{BaP}$, showed a significant induction over solvent control and control treatment for 0 and $5 \%$ peat (Fig. 1A). EROD activity increased significantly from 2.4 to 1.6 -fold compared to solvent control, for 0 and $5 \%$ peat respectively (ANOVA, $\mathrm{p}<0.001$ ). No increase was observed for $2.5 \%$ peat (ANOVA, $\mathrm{p}=0.12$ ). For EROD activity measured in larvae exposed to Fluo-spiked sediment with $2.5 \%$ peat (Fig. 1B), a significant 2.4-fold induction was observed over the solvent control (ANOVA, $\mathrm{p}=0.03$ ) but not over the control treatment (ANOVA, $\mathrm{p}=0.58$ ). No significant difference in EROD activity was, however, recorded between both controls (ANOVA, $\mathrm{p}=0.33$ ). Similarly, no significant difference was observed in larvae exposed to Fluo spiked-sediment with $0 \%$ and $5 \%$ peat (ANOVA, $\mathrm{p}=0.22$ and $\mathrm{KW}, \mathrm{p}=0.05$ respectively).

\subsection{Photomotor behavioral response of larvae}

Zebrafish larvae PMR: PMR of zebrafish larvae (at $120 \mathrm{hpf}$ ) exposed to $\mathrm{BaP}$ in different conditions of peat are shown in Fig. 2. The response patterns of larvae were similar for each peat condition showing an increase in the distance moved during the stress period (light off). BaP larvae swimming activity was significantly reduced compared to the control treatment only in light off period for $0 \%$ peat condition (Fig. 2A). Fish from all treatments $2.5 \%$ and $5 \%$ showed a similar response pattern to the challenge and no significant differences in swimming activity were observed (Student's t, p>0.05) (Fig. 2B, 2C). PMR of zebrafish larvae (at $120 \mathrm{hpf}$ ) exposed to Fluo in different conditions of peat are shown in Fig. 3. Swimming activity was significantly decreased whatever the light/dark periods for the condition without peat (Fig. 3A). No significant differences 
were observed between Fluo and solvent treatments for $2.5 \%$ and $5 \%$ peat conditions (Student's t, $p>0.05$ ) (Fig. 3B, 3C).

Japanese medaka larvae PMR: PMR of Japanese medaka (14 dpf) exposed to BaP and Fluo are shown in Fig. 4. The first dark period is performed to stabilize the swimming activity of larvae. The response patterns of larvae were similar for each peat condition showing an increased swimming activity during light off (2) period. The larvae exposed to $\mathrm{BaP}$ for $0 \%$ peat condition, swam significantly greater distances than solvent control larvae (Fig. 4A). The swimming activity of larvae exposed to Fluo for $0 \%$ peat condition was not significantly different compared to solvent control (ANOVA, $\mathrm{p}>0.05$ ). Regarding $2.5 \%$ peat condition, whatever PAH considered, no significant differences in swimming activity were observed (ANOVA, $p>0.05$ ). PMR of larvae in $5 \%$ peat condition showed an opposite response pattern to the larvae in condition without peat. The distance moved by BaP-exposed larvae was only significantly lower in the first light period compared to solvent control larvae. Fluo-exposed larvae swam significantly 1.9-fold less for light on (1) and 1.8-fold less for light off (2) periods than solvent control larvae.

\section{Discussion}

In recent decades, a number of different ecotoxicity tests have been established demonstrating the robustness of fish embryo-larval assays to reflect the toxicity of organic pollutants. Zebrafish (Danio rerio) and Japanese medaka (Oryzias latipes) have shown reliable results in sediment contact tests using natural and spiked sediment (Barjhoux et al. 2012; Hollert et al. 2003; Vicquelin et al. 2011). The responses of zebrafish (this study) and Japanese medaka (Le Bihanic et al. 2014) to two PAH models, BaP and Fluo, were recorded in order to define an artificial sediment while assessing the influence on the sediment composition (mainly organic matter variation) on the toxicity of these both molecules. Using similar PAH-spiked sediment, exposure routes and toxicity endpoints at the molecular (EROD activity), morphological and behavioral levels, it was shown that toxicity thresholds and the intensity of responses of both these species were different.

Our results on zebrafish as well as medaka embryo-larval assays, suggest that PAH bioavailability is reduced by increasing the content of organic matter in the artificial sediment. This finding is consistent with field studies demonstrating that the bioavailability of PAH is highly dependent on the concentration of organic matter and their interaction, which can reduce the freely dissolved PAH and their bioaccumulation in organisms (Fanget et al. 2002; Guasch et al. 2012). Furthermore, the spiking efficiencies of BaP in the prepared sediments also support this postulation, but not for Fluo. Indeed, a reduction of Fluo-spiking efficiency was observed with increasing peat concentration. The high sorption capacity of compounds to the organic matter is linked to their molecular surface area (related to their molecular weight), which manage their high hydrophobicity natures of both $\mathrm{BaP}\left(\log \mathrm{K}_{\mathrm{ow}}=6.04\right)$ and Fluo (Log $\left.\mathrm{K}_{\mathrm{ow}}=5.16\right)$ and their partitioning and bioavailability. Humic substances act as a trap for hydrophobic molecules which in turn reduce both their dissolved concentrations in the water column and their subsequent bioaccumulation in living organisms (Akkanen and Kukkonen 2003; Akkanen et al. 2005; Haitzer et al. 1999; Laor et al. 1998; Mayer et al. 2007).

$\mathrm{BaP}$ exposure did not induce mortality, hatching failure or delayed hatching in zebrafish embryo-larval assays. Moreover, BaP did not lead to teratogenic effects (Table 3). Somewhat different results have been reported for 
BaP-exposed medaka embryos (Le Bihanic et al. 2014b). A low teratogenic effect was observed in medaka, but contrary to zebrafish, BaP was shown to delay hatching. This compound is not known to directly induce developmental effects. In contrast with BaP-exposed zebrafish larvae, significant biometric developmental defects were observed in Fluo-exposed embryos. These effects are reflected by an increasing mortality, a lack of embryo hatching and alterations in growth and development (Tables 2 and 3). Although morphological abnormalities are currently used as sensitive endpoints in embryo-larval assay (Lammer et al. 2009; Nagel 2002), neither oedemas, axial skeleton, craniofacial nor cardiovascular abnormalities were significantly recorded during Fluo exposure. Furthermore, the decrease in larval standard length and the increase in their yolk sac area caused by Fluo exposure in the absence of peat attest to a developmental delay.

Zebrafish larval behavioral assay was a robust endpoint in toxicity testing (Ali et al. 2012; Bilotta et al. 2002; MacPhail et al. 2009). The assessment of the developmental neurotoxic effects of various compounds can be analyzed through their swimming capacity, stress-regulating systems and motor responses (perception and reaction) to stimuli (Champagne et al. 2010; Drapeau et al. 2002; de Esch et al. 2012; Linney et al. 2004). Studies regarding behavioral effects in fish have been extensively reported using psychotropic substances (Ali et al. 2012; Cowden et al. 2012; Kokel et al. 2010; Padilla et al. 2011; Rihel et al. 2010) but poorly investigated for other pollutants. In the present study, a significant decrease of PMR in zebrafish was observed for the highest concentration of Fluo in the absence of peat. Moreover for each peat concentration tested, the zebrafish larvae presented a similar behavioral pattern (Fig. 3). The first light period (5 min in duration, light on (1)) reflected basal activity which was followed by an excitation phase characterized by an increase in locomotor activity during the sudden darkness period. Then, a return to the basal activity period corresponding to a recovery phase was observed (light on (2)). This pattern of response is consistent with previous results reported in the literature (Kokel et al. 2010; MacPhail et al. 2009; Padilla et al. 2011). Concerning Japanese medaka, the potential toxicity of PAH on larval behavior assays has been only recently analyzed and only for PAHs in mixture (Le Bihanic et al. 2014a). BaP led to an increase in PMR in the absence of peat which was suppressed in the highest tested peat concentration. In contrast, Fluo decreased in PMR in this later exposure condition. The Japanese medaka PMR pattern was similar to that for zebrafish. Only a few studies have examined the impact of organic pollutant on the fish PMR. Using a similar approach, Péan et al. (2013) reported a stimulation of this PMR following PCB contamination transferred to offspring zebrafish larvae. Furthermore, changes in zebrafish swimming rates, depending on PBDE congeners, have been shown by Usenko et al. (2011). Additionally, a PAH lethargic effect on hunting behavior and visual acuity was demonstrated by Gonçalves et al. (2008) in juveniles gilthead seabream (Sparus aurata). Even more poorly explored, the behavioral effects of organic pollutants clearly merit further research.

At the molecular level, significant induction of enzymatic EROD activity in zebrafish assays only appeared in the absence of peat and at the highest peat concentration during BaP exposure (Fig. 1A). The EROD activity modulation by $\mathrm{BaP}$ is in general agreement with $\mathrm{AhR}$ agonist properties of this compound. The ability of $\mathrm{BaP}$ to induce EROD activity (indicator of phase I biotransformation activities) through the AhR2 pathway has been established in marine fish (Au et al. 2004; Barron et al. 2004) and freshwater fish (Bols et al. 1999; Costa et al. 2011; Incardona et al. 2011; Noury et al. 2006). Regarding the results of Fluo exposure, no significant induction of EROD activity was observed compared to the control treatment. A mild induction of EROD activity was observed for $2.5 \%$ peat condition compared to $2.5 \%$ peat solvent control. EROD activity in this control is rather 
low compared to other control conditions; therefore induction of EROD in $2.5 \%$ peat condition may not be meaningful. The absence (or weak) induction of EROD by Fluo is in agreement with the inhibitory activity of this PAH on cytochrome P4501A enzyme (Van Tiem and Di Giulio 2011; Willett et al. 2001; Willett et al. 1998).

The toxicity of both hydrophobic compounds was consistent with their toxic properties. BaP is known as having a mutagenic mode of action for inducing tumor formation, and is thought to require metabolic activation to become carcinogenic (Carlson et al. 2004; Costa et al. 2011; Wessel et al. 2010). Furthermore, some studies have demonstrated the cardiotoxic action of AhR-mediated compounds such as the BaP (Huang et al. 2012; Incardona et al. 2006; Matson et al. 2008). Our results did not corroborate with previous studies. However, we have to be caution about these conclusions because we used only crude analysis of cardiotoxicity. Even if relatively few studies focus the toxicity of Fluo, this compound has mutagenic mode of action rather inducing teratogenic defects (Vicquelin 2011; Wessel et al. 2012). When we compare the findings from the experiment on zebrafish and medaka, it appears that the toxicity of PAHs is dependent on their bioavailability, directly related to their adsorption ability on particles of peat. In sediment, the 5-ring BaP appeared less bioavailable than the 3-benzenic rings Fluo for accumulation in fish. These findings are consistent with the studies of Varanasi et al. (1985) and Djomo et al. (1996) which demonstrated that the uptake rate of 4,5-ring PAHs are lower than those of 2,3-ring PAHs. Indeed, in the absence of peat, Fluo may be more labile and consequently more easily uptaked by embryos. Fluo may have passed passively through the chorion, and led to adverse effects on embryos. Indeed, lethal effects were reported in zebrafish and a high proportion of abnormalities were observed in medaka. The bioavailability pattern of Fluo for zebrafish and medaka embryos was somewhat different for $2.5 \%$ and $5 \%$ peat. Particles of blond peat were seen to be fixed to the surface of clay particles and to limit PAHs accessibility to binding sites, decreasing exchanges and PAHs metabolisation (Fanget et al. 2002). However, following Fluo exposure, important biometric defects and developmental time retardation were observed in zebrafish at the highest concentration of peat (5\%). Because of the high proportion of peat, PAHs on binding sites could be saturated and would be then slightly less available for embryos than in condition without peat not leading to lethal effects. All these results proved that zebrafish seem to be more sensitive to the physical properties of sediment compared to medaka. This sediment tended to clog egg pores, might limit optimal gas exchange and therefore alter embryonic development.

Taking into consideration the results of both embryo-larval toxicity testing with zebrafish and medaka (Le Bihanic et al. 2014b), an artificial sediment without peat was suitable for zebrafish and with $2.5 \%$ peat for medaka. Similar biological responses of zebrafish and medaka larvae were reported after exposure to BaP for the sediment containing $0 \%$ and $5 \%$ peat (Table 4), leading to any change in survival, hatching kinetic and morphology. At individual level, a modification of the behavioral response were noted for the both species (lethargy or hyperactivity), showing a potential neurotoxic effect of BaP. These effects were also linked with a metabolic activation of detoxification process for the zebrafish. An opposite toxicity response were observed at the intermediate concentration of peat $(2.5 \%)$ between the both species. BaP appeared more available for medaka, leading to hatching kinetic and morphometric alterations, whereas no disrupts and metabolic activation were recorded for zebrafish larvae. The biological response of Japanese medaka were in agreement with previous studies (Vicquelin 2011; Wassenberg and Di Giulio 2004). Regarding Fluo exposures, completely opposite toxicity responses were also reported in both species for each artificial sediment tested (Table 5). Acute 
toxicity effects of Fluo were recorded in zebrafish at $0 \%$ and $5 \%$ peat content compared to Japanese medaka. These effects were expressed by embryo-larval mortality, hatching, morphometric alterations and a significant lethargic activity of fish. The intensity of effects was more representative of Fluo intrinsic toxicity at $0 \%$ than 5 $\%$ peat due to higher bioavailability for zebrafish. In contrast, the embryotoxicity was more pronounced in medaka at $2.5 \%$ peat, which is in total agreement with individual and population-based levels recorded after sediment contact exposures in previous study for similar species (Vicquelin 2011).

The primary purpose of this experiment was to develop an artificial sediment resembling a composition of natural sediment in order to standardize sediment exposure methods. Regarding all results for both species with respect to ethical requirements (3R principles and early developmental stages guidelines), Medaka embryo-larval assay with sediment contact appears to be more robust than zebrafish embryo-larval assay for revealing $\mathrm{BaP}$ and Fluo toxic effects and more resilient to the physico-chemical properties of sediment. This higher degree of sensitivity of zebrafish could be due to a higher porosity of chorion and therefore the higher diffusion of compounds (see the section on acute effects). Using a concentration set to $2.5 \%$ peat, the degree of sensitivity of the medaka would be mainly due to its sensitivity to PAHs and to a longer exposure duration during the critical embryonic developmental period, as well as due to the metabolic activity. Indeed, the embryonic phase in medaka at $26{ }^{\circ} \mathrm{C}$ ranges from 10 to 11 days compared to 2 days in zebrafish (Kimmel et al. 1995; Padilla et al. 2009). In this context, our findings support the premise that medaka would constitute a better model for testing the toxicity of hydrophobic chemicals (such as PAHs) testing than zebrafish, although zebrafish assay has been demonstrated to be a valuable alternative when short-time exposures are targeted. The use of finer markers representative of the early toxic actions of hydrophobic compounds, in addition to conventional phenotypic endpoints, would appear to be essential in predicting their toxicity (Voelker et al. 2007) as it will increase the sensitivity and relevance of biological responses. In the absence of this information, molecule or treatment safety could be over or underestimated.

\section{Conclusion}

As a complement to previous research into Japanese medaka by Le Bihanic et al. (2014), our study validated the use of artificial sediment for developmental toxicity testing using fish embryo-larval assay for Japanese medaka. Suitable artificial sediment comprises $92.5 \% \mathrm{dw}$ of $0.2-0.5 \mathrm{~mm}$ silica, $5 \% \mathrm{dw}$ kaolin clay and $2.5 \% \mathrm{dw}$ Sphagnum blond peat. This composition was not suitable for zebrafish for which responses were more sensitive to sediment without organic matter. Consequently, this suggests that a common protocol cannot be proposed for these two species from an OECD guidelines point of view. Furthermore, this study demonstrated that two physiologically-close fish species exhibited differences in their ability to reflect the relative developmental toxicities of hydrophobic organic pollutants. These differences might be explained by differences in their developmental kinetics (leading to a different exposure duration), 2) in their adsorption/metabolisation capacities and cell damage repair abilities. It also important to take accounts the influence of the sediment composition on the bioavailability and toxicity of chemicals, to better comparison of sediment toxicity tests. We elicit concerns about the real robustness of zebrafish in toxicity testing using sediment contact exposure. Japanese medaka appear better suited to toxicity assessment of hydrophobic compounds such as PAHs. Finally, to avoid any 
misinterpretation regarding the risk assessment to human or environment health, we recommend that several OECD fish species should be systematically considered.

\section{Acknowledgments}

Financial support for $\mathrm{PhD}$ grants was received by FLB from the Ministère de l'Enseignement de Supérieur et de la Recherche and by PP from both the Conseil Général de Charente Maritime and the Institut Français de Recherche pour l'Exploitation de la Mer (Ifremer). This research was supported by the French Agence Nationale pour la Recherche, program "Contaminant, Ecosystème et Santé", within the framework of the ConPhyPoP (2009-002) research project and CPER A2E. This project is co-financed by the European Union with the European Regional Development Fund. S. Keiter and H. Zielke are acknowledged for their recommendation on sediment preparation and the Sibelco Company for generously providing sand. D. Leguay is acknowledged for technical support of zebrafish behavioral assays and L. Lyphout for help in the zebrafish breeding maintenance. This research was part of the LABEX COTE cluster of excellence "continental to coastal ecosystems".

\section{References}

Ahlf W, Hollert H, Neumann-Hensel H, Ricking M (2002) A guidance for the assessment and evaluation of sediment quality. J Soils Sediments 2:37-42.

Akkanen J, Kukkonen JVK (2003) Measuring the bioavailability of two hydrophobic organic compounds in the presence of dissolved organic matter. Environ Toxicol Chem 22:518-524.

Akkanen J, Lyytikäinen M, Tuikka A, Kukkonen JVK (2005) Dissolved organic matter in pore water of freshwater sediments: effects of separation procedure on quantity, quality and functionality. Chemosphere 60:1608-1615.

Ali S, Champagne DL, Richardson MK (2012) Behavioral profiling of zebrafish embryos exposed to a panel of 60 water-soluble compounds. Behav Brain Res 228:272-83.

Au DWT, Chen P, Pollino C (2004) Cytological changes in association with ethoxyresorufin o-deethylase induction in fish upon dietary exposure to benzo[a]pyrene. Environ Toxicol Chem 23:1043-1050.

Barjhoux I, Baudrimont M, Morin B, Landi L, Gonzalez P, Cachot J (2012). Effects of copper and cadmium spiked-sediments on embryonic development of Japanese medaka (Oryzias latipes). Ecotoxicol Environ Saf 79:272-282.

Barron MG, Carls MG, Heintz R, Rice SD (2004) Evaluation of fish early life-stage toxicity models of chronic embryonic exposures to complex polycyclic aromatic hydrocarbon mixtures. Toxicol Sci 78:60-67.

Bartzke M, Delov V, Stahlschmidt-Allner P, Allner B, Oehlmann J (2010) Integrating the fish embryo toxicity test as triad element for sediment toxicity assessment based on the Water Framework Directive approach. J Soils Sediments 10:389-399.

Baumard P, Budzinski H, Garrigues P (1998) Polycyclic aromatic hydrocarbons in sediments and mussels of the western mediterranean sea. Environ Chem 17:765-776. 
Baumard P, Budzinski H, Garrigues P, Narbonne JF (1999). Polycyclic aromatic hydrocarbon (PAH) burden of mussels (Mytilys sp.) in different marine environments in relation with sediment PAH contamination, and bioavailability. Mar Environ Res 47:415-439.

Behar F, Leblond C, Saint-Paul C (1989) Analysis of pyrolysis effluents in an open and closed system. Oil and Gas Sci Technol 44:387-411.

Belanger SE, Balon EK, Rawlings JM (2010) Saltatory ontogeny of fishes and sensitive early life stages for ecotoxicology tests. Aquat Toxicol 97:88-95.

Benlahcen KT, Chaoui A, Budzinski H, Bellocq J, Garrigues PH (1997). Distribution and sources of polycyclic aromatic hydrocarbons in some mediterranean coastal sediments. Mar Pollut Bull 34:298-305.

Bilotta J, Saszik S, Givin CM, Hardesty HR, Sutherland SE (2002) Effects of embryonic exposure to ethanol on zebrafish visual function. Neurotoxicol Teratol 24:759-766.

Bols NC, Schirmer K, Joyce EM, Dixon DG, Greenberg BM, Whyte JJ (1999) Ability of polycyclic aromatic hydrocarbons to induce 7-ethoxyresorufin-o-deethylase activity in a trout liver cell line. Ecotoxicol Environ Saf 44:118-128.

Braunbeck T, Boettcher M, Hollert H, Kosmehl T, Lammer E, Leist E, Rudolf M, Seitz N (2005) Towards an alternative for the acute fish $\mathrm{LC}(50)$ test in chemical assessment: the fish embryo toxicity test goes multispecies -- an update. Altex 22:87-102.

Budzinski H, Letellier M, Thompson S, LeMenach K, Garrigues P (2000) Combined protocol for the analysis of polycyclic aromatic hydrocarbons (PAHs) and polychlorobiphenyls (PCBs) from sediments using focussed microwave assisted (FMW) extraction at atmospheric pressure. Fresenius J Analyt Chem 367:165-171.

Burton JGA (2002) Sediment quality criteria in use around the world. Limnol 3:65-76.

Cachot J, Geffard O, Augagneur S, Lacroix S, Le Menach K, Peluhet L, Couteau J, Denier X, Devier MH, Pottier D, Budzinski H (2006) Evidence of genotoxicity related to high PAH content of sediments in the upper part of the Seine estuary (Normandy, France). Aquat Toxicol 79:257-267.

Carlson E, Li Y, Zelikoff JT (2004) Benzo[a]pyrene-induced immunotoxicity in Japanese medaka (Oryzias latipes): relationship between lymphoid CYP1A activity and humoral immune suppression. Toxicol Appl Pharmacol 201:40-52.

Carney SA, Peterson RE, Heideman W (2004) Hydrocarbon receptor / aryl hydrocarbon receptor nuclear translocator pathway causes developmental toxicity through a CYP1A-independent mechanism in zebrafish. Molecular Pharmacol 66:512-521.

Castaño A, Bols N, Braunbeck T, Dierickx P, Halder M, Isomaa B, Kawahara K, Lee LEJ, Mothersill C, Pärt P, Repetto G, Sintes JR, Rufli H, Smith R, Wood C, Segner H (2003) The use of fish cells in ecotoxicology. Alter to Lab Anim 31:317-351.

Champagne DL, Hoefnagels CCM, de Kloet RE, Richardson MK (2010) Translating rodent behavioral repertoire to zebrafish (Danio rerio): relevance for stress research. Behav Brain Res 214:332-342.

Costa J, Ferreira M, Rey-Salgueiro L, Reis-Henriques MA (2011) Comparision of the waterborne and dietary routes of exposure on the effects of Benzo(a)pyrene on biotransformation pathways in Nile tilapia (Oreochromis niloticus). Chemosphere 84:1452-1460. 
Cowden J, Padnos B, Hunter D, MacPhail R, Jensen K, Padilla S (2012) Developmental exposure to valproate and ethanol alters locomotor activity and retino-tectal projection area in zebrafish embryos. Reprod Toxicol 33:165-73.

Dabestani R, Ivanov IN (1999) A compilation of physical, spectroscopic and photophysical properties of polycyclic aromatic hydrocarbons. Photochem and Photobiol 70:10-34.

Daouk T (2011) Effets de contaminations d'embryons et d'adultes de poissons zèbres (Danio rerio) par des PCB et des HAP. Ph D. Thesis (in French), 162 pages.

Djomo JE, Garrigues P, Narbonne JF (1996) Uptake and depuration of polycyclic aromatic hydrocarbons from sediment by the zebrafish (Brachydanio rerio). Environ Toxicol Chem 15:1177-1181.

Drapeau P, Saint-Amant L, Buss RR, Chong M, McDearmid JR, Brustein E (2002) Development of the locomotor network in zebrafish. Prog Neurobiol 68:85-111.

EC (2000). Directive 2000/60/EC of the European Parliament and of the Council of 2000, October $23^{\text {rd }}$. Framework for Community action in the field of water policy. Off J Eur Parliament L327:1-82.

El Nemr A, Said TO, Khaled A, El-Sikaily A, Abd-Allah AM (2007). The distribution and sources of polycyclic aromatic hydrocarbons in surface sediments along the Egyptian Mediterranean coast. Environ Monit Assess 124:343-359.

Embry MR, Belanger SE, Braunbeck T, Galay-Burgos M, Halder M, Hinton DE, Léonard M, Lillicrap A, Norberg-King T, Whale G (2010) The fish embryo toxicity test as an animal alternative method in hazard and risk assessment and scientific research. Aquat Toxicol 97:79-87.

De Esch C, van der Linde H, Slieker R, Willemsen R, Wolterbeek A, Woutersen R, De Groot D (2012) Locomotor activity assay in zebrafish larvae: influence of age, strain and ethanol. Neurotoxicol Teratol $34: 425-433$.

EU (2010). Directive 2010/63/EU of the European Parliament and of the Council of 2010, September $22^{\text {nd }}$. Legislation for the protection of animals used for scientific purposes. Off J Eur Union L276/33-79.

Fallahtafti S, Rantanen T, Brown RS, Snieckus V, Hodson P V (2012). Toxicity of hydroxylated alkylphenanthrenes to the early life stages of Japanese medaka (Oryzias latipes). Aquat Toxicol 106-107:5664.

Fang X, Thornton C, Scheffler BE, Willett KL (2013). Benzo[a]pyrene decreases global and gene specific DNA methylation during zebrafish development. Environ Toxicol Pharmacol 36:40-50.

Fanget B, Devos O, Naffrechoux E (2002) Rôle des acides humiques dans le transfert du pyrène entre les minéraux argileux et l'eau. Rev Sci Eau 15:95-108.

Farwell A, Nero V, Croft M, Bal P, Dixon DG (2006) Modified Japanese medaka embryo-larval bioassay for rapid determination of developmental abnormalities. Arch Environ Contam Toxicol 51:600-607.

Feiler U, Höss S, Ahlf W, Gilberg D, Hammers-Wirtz M, Hollert H, Meller M, Neumann-Hensel H, Ottermanns R, Seiler T-B, Spira D, Heininger P (2013) Sediment contact tests as a tool for the assessment of sediment quality in German waters. Environ Toxicol Chem 32:144-155.

Gerlai R (2011) A small fish with a big future: zebrafish in behavioral neuroscience. Rev Neurosci 22:3-4.

Gonçalves R, Scholze M, Ferreira AM, Martins M, Correia AD (2008) The joint effect of polycyclic aromatic hydrocarbons on fish behavior. Environ Res 108:205-213. 
Guasch H, Ginebreda A, Geiszinger A, Akkanen J, Slootweg T, Mäenpää K, Agbo S, Gallampois C, Kukkonen JVK (2012) Bioavailibility of Organic Contaminants in Freshwater Environments. The Handbook Environ Chem, Berlin, Heidelberg, pp 53.

Haitzer M, Höss S, Traunspurger W, Steinberg C (1999) Relationship between concentration of dissolved organic matter (DOM) and the effect of DOM on the bioconcentration of benzo[a]pyrene. Aquat Toxicol 45:147-158.

Halder M, Léonard M, Iguchi T, Oris JT, Ryder K, Belanger SE, Braunbeck T a, Embry MR, Whale G, NorbergKing T, Lillicrap A (2010) Regulatory aspects on the use of fish embryos in environmental toxicology. Integrated Environ Assess Manag 6:484-491.

Hawliczek A, Nota B, Cenijn P, Kamstra J, Pieterse B, Winter R, Winkens K, Hollert H, Segner H, Legler J (2012). Developmental toxicity and endocrine disrupting potency of 4-azapyrene, benzo[b]fluorene and retene in the zebrafish Danio rerio. Reprod Toxicol 33:213-223.

Heintz RA, Rice SD, Wertheimer AC, Bradshaw RF, Thrower FP, Joyce JE, Short JW (2000). Delayed effects on growth and marine survival of pink salmon Oncorhynchus gorbuscha after exposure to crude oil during embryonic development. Mar Ecol Prog Ser 208:205-216.

Hengstler JG, Foth H, Kahl R, Kramer P, Lilienblum W, Schulz T, Schweinfurth H (2006) The REACH concept and its impact on toxicological sciences. Toxicol 220:232-239.

Hill AJ, Teraoka H, Heideman W, Peterson RE (2005) Zebrafish as a model vertebrate for investigating chemical toxicity. Toxicol Sci 86:6-19.

Hollert H, Dürr M, Erdinger L, Braunbeck T (2000) Cytotoxicity of settling particulate matter and sediments of the neckar river (Germany) during a winter flood. Envir Toxicol Chem 19:528-534.

Hollert H, Keiter S, König N, Rudolf M, Ulrich M, Braunbeck T (2003) A new sediment contact assay to assess particle-bound pollutants using zebrafish (Danio rerio) embryos. J Soils Sediments 3:197-207.

Höss S, Ahlf W, Fahnenstich C, Gilberg D, Hollert H, Melbye K, Meller M, Hammers-Wirtz M, Heininger P, Neumann-Hensel H, Ottermanns R, Ratte H-T, Seiler T-B, Spira D, Weber J, Feiler U (2010) Variability of sediment-contact tests in freshwater sediments with low-level anthropogenic contamination-determination of toxicity thresholds. Environ Pollut 158:2999-3010.

Huang L, Wang C, Zhang Y, Li J, Zhong Y, Zhou Y, Chen Y, Zuo Z (2012). Benzo[a]pyrene exposure influences the cardiac development and the expression of cardiovascular relative genes in zebrafish (Danio rerio) embryos. Chemosphere 87:369-375.

Incardona JP, Day HL, Collier TK, Scholz NL (2006). Developmental toxicity of 4-ring polycyclic aromatic hydrocarbons in zebrafish is differentially dependent on $\mathrm{AH}$ receptor isoforms and hepatic cytochrome P4501A metabolism. Toxicol Appl Pharmacol 217:308-21.

Incardona JP, Linbo TL, Scholz NL (2011) Cardiac toxicity of 5-ring polycyclic aromatic hydrocarbons is differentially dependent on the aryl hydrocarbon receptor 2 isoform during zebrafish development. Toxicol Appl Pharmacol 257:242-249.

van der Jagt K, Munn S, Torslov J, de Bruijn J (2004) Alternative approaches can reduce the use of test animals under REACH. Addendum to the report of the European Commission: Assessment of additional testing needs under REACH effects of(Q)SARS, risk based testing and voluntary industry initiatives 1-85. 
Kerambrun E, Henry F, Perrichon P, Courcot L, Meziane T, Spilmont N, Amara R (2012). Growth and condition indices of juvenile turbot, Scophthalmus maximus, exposed to contaminated sediments: Effects of metallic and organic compounds. Aquat Toxicol 108:130-140.

Kimmel CB, Ballard WW, Kimmel SR, Ullmann B, Schilling TF (1995) Stages of embryonic development of the zebrafish. Dev Dynam 203:253-310.

Kokel D, Bryan J, Laggner C, White R, Cheung CYJ, Mateus R, Healey D, Kim S, Werdich A a, Haggarty SJ, Macrae C a, Shoichet B, Peterson RT (2010) Rapid behavior-based identification of neuroactive small molecules in the zebrafish. Nat Chem Biol 6:231-237.

Kosmehl T, Hallare A V, Reifferscheid G, Manz W, Braunbeck T, Hollert H (2006) A novel contact assay for testing genotoxicity of chemicals and whole sediments in zebrafish embryos. Environ Toxicol Chem 25:2097-2106.

Köthe H (2003) Existing Sediment Management Guidelines : An Overview What will happen with the sediment / dredged material ? J Soils Sediments 3:139-143.

Lammer E, Carr GJ, Wendler K, Rawlings JM, Belanger SE, Braunbeck T (2009) Is the fish embryo toxicity test (FET) with the zebrafish (Danio rerio) a potential alternative for the fish acute toxicity test? Comp Biochem Physiol Part C, Pharmacol, Toxicol Endocrinol 149:196-209.

Landrum PF, Lotufo GR, Gossiaux DC, Gedeon ML, Lee J-H (2003) Bioaccumulation and critical body residue of PAHs in the amphipod, Diporeia spp: additional evidence to support toxicity additivity for PAH mixtures. Chemosphere 51:481-489.

Laor Y, Farmer WJ, Aochi Y, Strom PF (1998) Phenanthrene binding and sorption to dissolved and to mineralassociated humic acid. Water Res 32:1923-1931.

Larcher T, Perrichon P, Vignet C, Ledevin M, Le Menach K, Lyphout L, Landi L, Clerandeau C, Le Bihanic F, Ménard D, Burgeot T, Akcha F, Cachot J, Cousin X (2014). Carcinogenic but no genotoxic effects detected following chronic trophic exposure of zebrafish to 3 fractions of Polycyclic Aromatic Hydrocarbons (PAHs). Environ Sci Pollut Res. doi:10.1007/s11356-014-2923-7.

Lawrence C (2007) The husbandry of zebrafish (Danio rerio): A review. Aquaculture 269:1-20.

Le Bihanic F, Perrichon P, Landi L, Clérandeau C, Le Menach K, Budzinski H, Cousin X, Cachot J (2014). Development of a reference artificial sediment for chemical testing adapted to the MELA sediment contact assay. Environ Sci Pollut Res. doi: 10.1007/s11356-014-2607-3 ;

Le Bihanic F, Clérandeau C, Le Menach K, Morin B, Budzinski H, Cousin X, Cachot J (2014a). Developmental toxicity of PAH mixtures in fish early life stages. Part II: adverse effects in Japanese medaka. Environ Sci Pollut Res. doi: 10.1007/s11356-014-2676-3;

Linney E, Upchurch L, Donerly S (2004) Zebrafish as a neurotoxicological model. Neurotoxicol Teratol 26:709_ 718.

Lockwood B, Bjerke S, Kobayashi K, Guo S (2004) Acute effects of alcohol on larval zebrafish: a genetic system for large-scale screening. Pharmacol Biochem Behav 77:647-654.

MacPhail RC, Brooks J, Hunter DL, Padnos B, Irons TD, Padilla S (2009) Locomotion in larval zebrafish: Influence of time of day, lighting and ethanol. Neurotoxicol 30:52-58.

Matson CW, Timme-Laragy AR, Di Giulio RT (2008). Fluoranthene, but not benzo[a]pyrene, interacts with hypoxia resulting in pericardial effusion and lordosis in developing zebrafish. Chemosphere 74:149-54. 
Mayer P, Fernqvist MM, Christensen PS, Karlson U, Trapp S (2007) Enhanced diffusion of polycyclic aromatic hydrocarbons in artificial and natural aqueous solutions. Environ Sci Technol 41:6148-6155.

Meador JP, Stein JE, Reichert WL, Varanasi U (1995). Bioaccumulation of polycyclic aromatic hydrocarbons by marine organisms. Reviews of Environ Contam Toxicol 143:79-165.

Nagel R (2002) DarT: The embryo test with the Zebrafish Danio rerio - a general model in ecotoxicology and toxicology. Altex 19:38-48.

Noury P, Geffard O, Tutundjian R, Garric J, Ecotoxicologie L (2006) Non Destructive In Vivo Measurement of Ethoxyresorufin Biotransformation by Zebrafish Prolarva: Development and Application. Environ Toxicol 324-331.

OECD (1998). Guidelines for the testing chemicals, Section 2: Effects on biotic systems, Test No. 212: Fish, Short-term toxicity test on embryo and sac-fry stages. 1-20.

OECD (2004). Guidelines for the testing chemicals, Section 2: Effects on biotic systems, Test No. 218: Sediment-water chironomid toxicity test using spiked sediment. 1-21.

OECD (2013a). Guidelines for the testing chemicals, Section 2: Effects on biotic systems, Test No. 210: Fish, early-life stage toxicity test.1-18.

OECD (2013b). Guidelines for the testing chemicals, Section 2: Effects on biotic systems, Test No. 236: Fish, Embryo Acute Toxicity (FET) Test.1-22.

van der Oost R, Beyer J, Vermeulen NPE (2003) Fish bioaccumulation and biomarkers in environmental risk assessment: a review. Environ Toxicol Pharmacol 13:57-149.

Otte JC, Schmidt AD, Hollert H, Braunbeck T (2010) Spatio-temporal development of CYP1 activity in early life-stages of zebrafish (Danio rerio). Aquat Toxicol 100:38-50.

Padilla S, Cowden J, Hinton DE, Yuen B, Law S, Kullman SW, Johnson R, Hardman RC, Flynn K, Au DWT (2009) Use of medaka in toxicity testing. Curr Protoc Toxicol. pp 1-36

Padilla S, Hunter DL, Padnos B, Frady S, MacPhail RC (2011) Assessing locomotor activity in larval zebrafish: Influence of extrinsic and intrinsic variables. Neurotoxicol Teratol 33:624-630.

Patel MR, Scheffler BE, Wang L, Willett KL (2006). Effects of benzo(a)pyrene exposure on killifish (Fundulus heteroclitus) aromatase activities and mRNA. Aquat Toxicol 77:267-278.

Péan S, Daouk T, Vignet C, Lyphout L, Leguay D, Loizeau V, Bégout M-L, Cousin X (2013) Long-term dietary-exposure to non-coplanar PCBs induces behavioral disruptions in adult zebrafish and their offspring. Neurotoxicol Teratol 39:45-56.

Rihel J, Prober D, Arvanites A, Lam K, Zimmerman S, Jang S, Haggarty SJ, Kokel D, Rubin LL, Peterson RT, Schier AF (2010) Zebrafish behavioral profiling links drugs to biological targets and rest/wake regulation. Science 327:348-351.

Russell WMS, Burch RL (1959) The Principles of humane experimental technique. 1-5.

Schneider C a, Rasband WS, Eliceiri KW (2012) NIH Image to ImageJ: 25 years of image analysis. Nat Methods 9:671-675.

Scholz S, Sela E, Blaha L, Braunbeck T, Galay-Burgos M, García-Franco M, Guinea J, Klüver N, Schirmer K, Tanneberger K, Tobor-Kapłon M, Witters H, Belanger S, Benfenati E, Creton S, Cronin MTD, Eggen RIL, Embry M, Ekman D, Gourmelon A, Halder M, Hardy B, Hartung T, Hubesch B, Jungmann D, Lampi M a, Lee L, Léonard M, Küster E, Lillicrap A, Luckenbach T, Murk AJ, Navas JM, Peijnenburg 
W, Repetto G, Salinas E, Schüürmann G, Spielmann H, Tollefsen KE, Walter-Rohde S, Whale G, Wheeler JR, Winter MJ (2013). A European perspective on alternatives to animal testing for environmental hazard identification and risk assessment. Regul Toxicol and Pharmacol 67:506-530. doi: 10.1016/j.yrtph.2013.10.003

Scott J, Incardona JP, Pelkki K, Shepardson S, Hodson P V (2010). AhR2-mediated, CYP1A-independent cardiovascular toxicity in zebrafish (Danio rerio) embryos exposed to retene. Aquatic Toxicology 2011;101:165-174.

Shen H, Huang Y, Wang R, Zhu D, Li W, Shen G, Wang B, Zhang Y, Chen Y, Lu Y, Chen H, Li T, Sun K, Li B, Liu W, Liu J, Tao S (2013) Global atmospheric emissions of polycyclic aromatic hydrocarbons from 1960 to 2008 and future predictions. Environ Sci Technol 47:6415-6424.

Spitsbergen J, Kent M (2003) The State of the Art of the Zebrafish Model for Toxicology and Toxicologic Pathology Research - Advantages and Current Limitations. Toxicol Pathol 31:62-87.

Strähle U, Scholz S, Geisler R, Greiner P, Hollert H, Rastegar S, Schumacher A, Selderslaghs I, Weiss C, Witters H, Braunbeck $\mathrm{T}$ (2012) Zebrafish embryos as an alternative to animal experiments--a commentary on the definition of the onset of protected life stages in animal welfare regulations. Reprod Toxicol 33:128-132.

Van Tiem LA, Di Giulio RT (2011) AHR2 knockdown prevents PAH-mediated cardiac toxicity and XRE- and ARE-associated gene induction in zebrafish (Danio rerio). Toxicol Appl Pharmacol 254:280-287.

Usenko CY, Robinson EM, Usenko S, Brooks BW, Bruce ED (2011) PBDE developmental effects on embryonic zebrafish. Environ Toxicol Chem 30:1865-1872.

Varanasi U, Reichert WL, Stein JE, Brown DW, Sanborn HR (1985) Bioavailability and biotransformation of aromatic hydrocarbons in benthic organisms exposed to sediment from an urban estuary. Environ Sci Technol 19:836-841.

Vicquelin L (2011). Caractérisation fine de la toxicité des hydrocarbures aromatiques polycycliques vis-à-vis des embryons et des larves de medaka japonais, Oryzias latipes. Contribution à l'évaluation des risques environnementaux associés à la pollution chimique des sédiments de l'estuaire de Seine. $\mathrm{Ph}$ D. thesis (in french), 319 pages.

Vicquelin L, Leray-Forget J, Peluhet L, LeMenach K, Deflandre B, Anschutz P, Etcheber H, Morin B, Budzinski H, Cachot J (2011) A new spiked sediment assay using embryos of the Japanese medaka specifically designed for a reliable toxicity assessment of hydrophobic chemicals. Aquat Toxicol 105:235-245.

Voelker D, Vess C, Tillmann M, Nagel R, Otto GW, Geisler R, Schirmer K, Scholz S (2007) Differential gene expression as a toxicant-sensitive endpoint in zebrafish embryos and larvae. Aquat Toxicol 81:355-364.

Wassenberg DM, Di Giulio RT (2004). Synergistic embryotoxicity of polycyclic aromatic hydrocarbon aryl hydrocarbon receptor agonists with cytochrome P4501A inhibitors in Fundulus heteroclitus. Environ Health Perspect 112:1658-1664.

Wessel N, Ménard D, Pichavant-Rafini K, Ollivier H, Le Goff J, Burgeot T, Akcha F (2012) Genotoxic and enzymatic effects of fluoranthene in microsomes and freshly isolated hepatocytes from sole (Solea solea). Aquat Toxicol 108:33-41.

Wessel N, Ollivier H, Goff J Le, Burgeot T (2010) The toxicity of benzo [a] pyrene on sole (Solea Solea) hepatocytes : assessment of genotoxic and enzymatic effects. Polycycl Aromat Comp 30:346-354. 
Willett K, Steinberg M, Thomsen J, Narasimhan TR, Safe S, Mcdonald S, Beattyt K, Kennicuttt MC (1995) Exposure of killifish to benzo[a]pyrene: comparative metabolism, DNA adduct formation and aryl hydrocarbon (Ah) receptor agonist activities. Comp Biochem Physiol 112B:93-103.

Willett KL, Randerath K, Zhou GD, Safe SH (1998) Inhibition of CYP1A1-dependent activity by the polynuclear aromatic hydrocarbon (PAH) fluoranthene. Biochem Pharmacol 55:831-839.

Willett KL, Wassenberg D, Lienesch L, Reichert W, Di Giulio RT (2001) In vivo and in vitro inhibition of CYP1A-dependent activity in Fundulus heteroclitus by the polynuclear aromatic hydrocarbon fluoranthene. Toxicol Appl Pharmacol 177:264-271.

Wölz J, Cofalla C, Hudjetz S, Roger S, Brinkmann M, Schmidt B, Schäffer A, Kammann U, Lennartz G, Hecker M, Schüttrumpf H, Hollert H (2009) In search for the ecological and toxicological relevance of sediment re-mobilisation and transport during flood events. J Soils Sediments 9:1-5.

\section{Figure Captions}

Fig. 1 In vivo measurement of EROD activity in 96 hpf zebrafish larvae exposed to BaP (A) and Fluo (B) for different peat sediment contents. All data are presented as mean of integrated density of pixels \pm SEM, $n=15$ per treatment. Asterisks indicate significant differences with control treatment and Dark traits between others treatments (ANOVA, $* \mathrm{p}<0.05$ and $* * * \mathrm{p}<0.001$ )

Fig. 2 PMR measured in $120 \mathrm{hpf}$ zebrafish larvae exposed to BaP. The locomotor activity of larvae in each 5 min periods of light/dark challenge was measured for different peat sediment contents: $0 \%$ peat (A), $2.5 \%$ peat (B), $5 \%$ peat (C). All data are presented as Mean \pm SEM, $n=30$ per treatment. Dark traits indicate significant differences with respective solvent control (Homogeneous triplicates, Student's t, $\mathrm{p}<0.05$ )

Fig. 3 PMR measured in 120 hpf zebrafish larvae exposed to Fluo. The locomotor activity of larvae in each 5min periods of light/dark challenge was measured for different peat sediment contents: $0 \%$ peat (A), $2.5 \%$ peat (B) and $5 \%$ peat (C). All data are presented as Mean \pm SEM, $n=30$ per treatment. Dark traits indicate significant differences with respect to solvent control treatment (Homogeneous triplicates, Student's t, $\mathrm{p}<0.05$ )

Fig. 4 PMR measured in 14 dpf Japanese medaka larvae exposed to BaP and Fluo. The locomotor activity of larvae in each 10-min periods of light/dark challenge was measured for different peat sediment contents: $0 \%$ peat (A), $2.5 \%$ peat (B) and $5 \%$ peat (C). All data are presented as Mean \pm SEM, $n=15$ per treatment. Dark traits indicate significant differences with solvent control treatment (ANOVA, $\mathrm{p}<0.05$ )

Fig. 1 Supplementary data Experimental design of zebrafish and medaka embryo-larval assays 

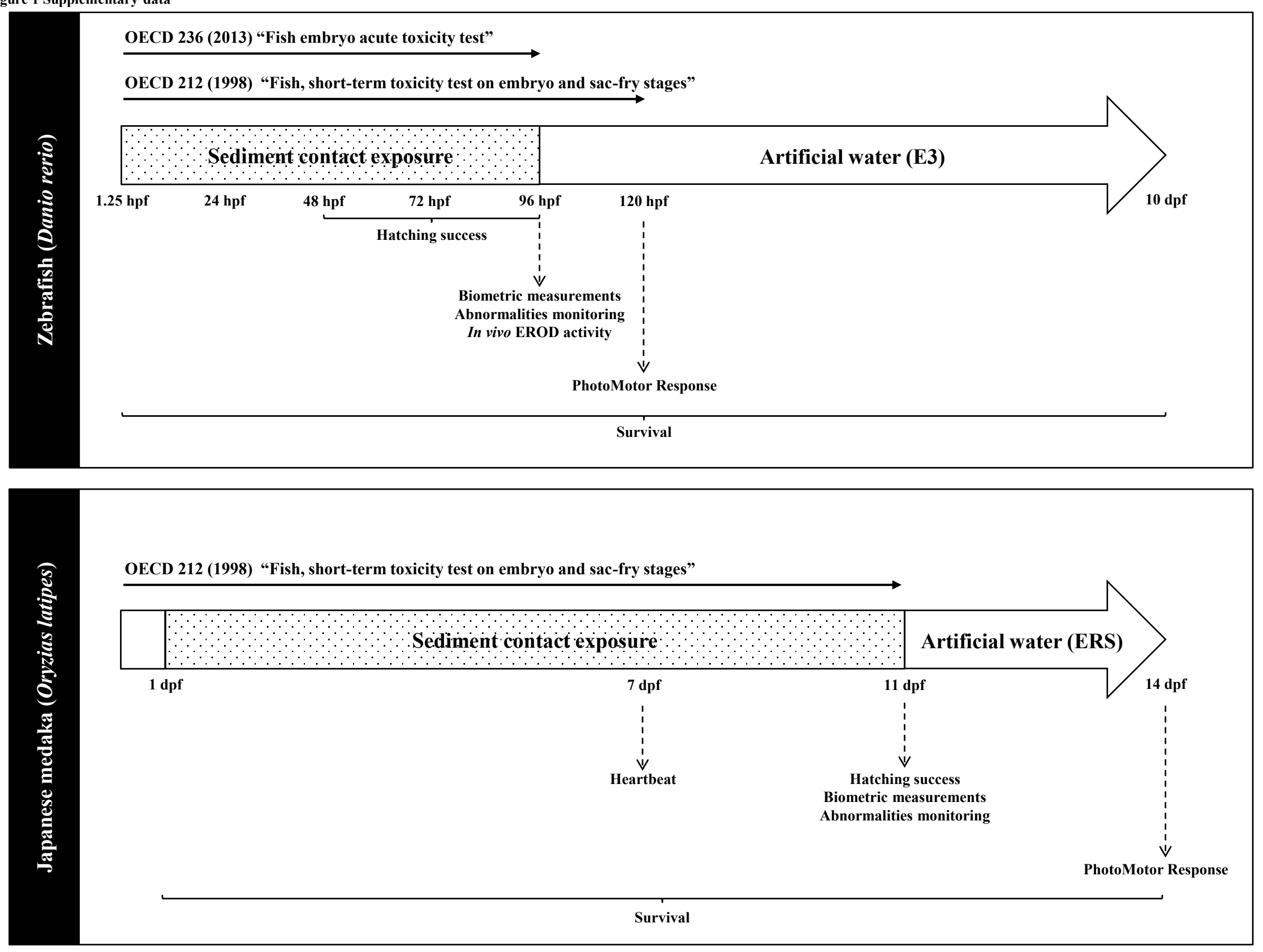
Figure 1

A

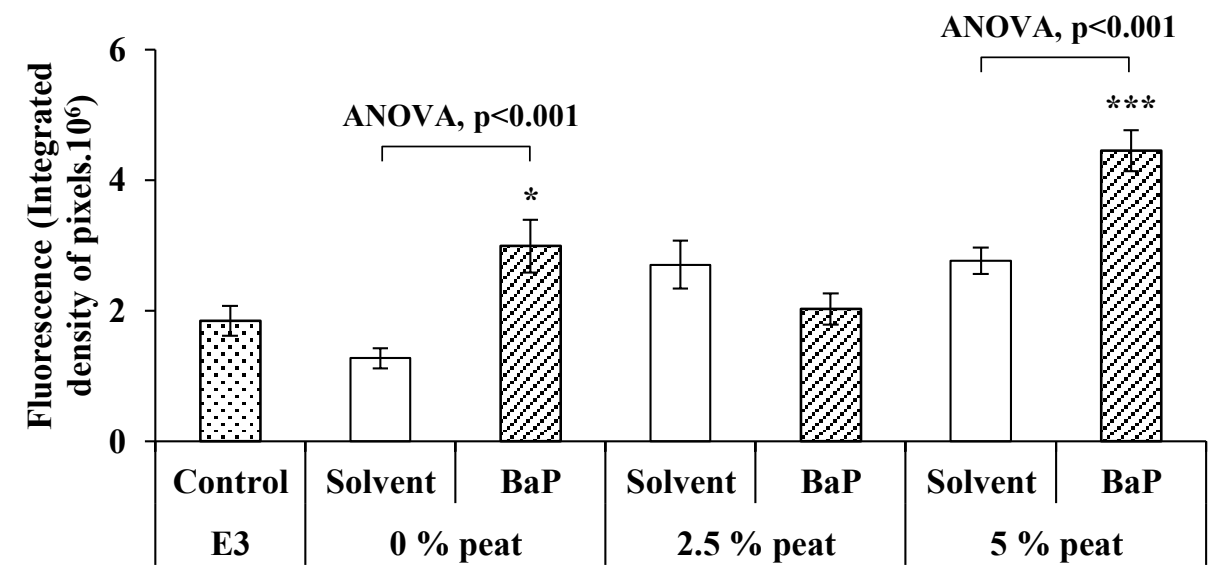

B

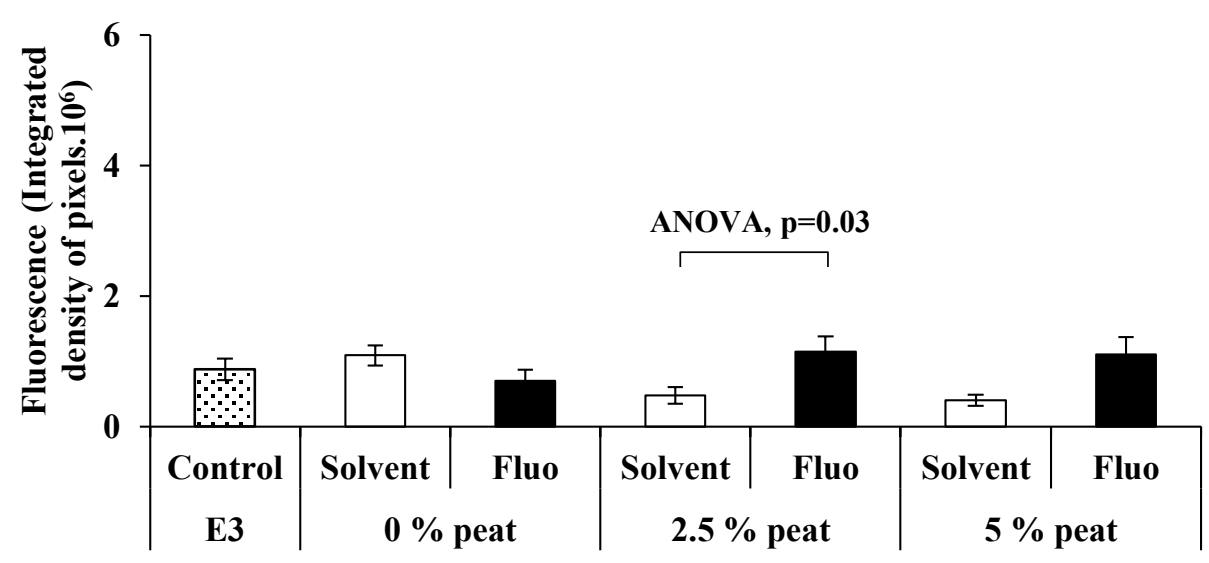


Figure 2

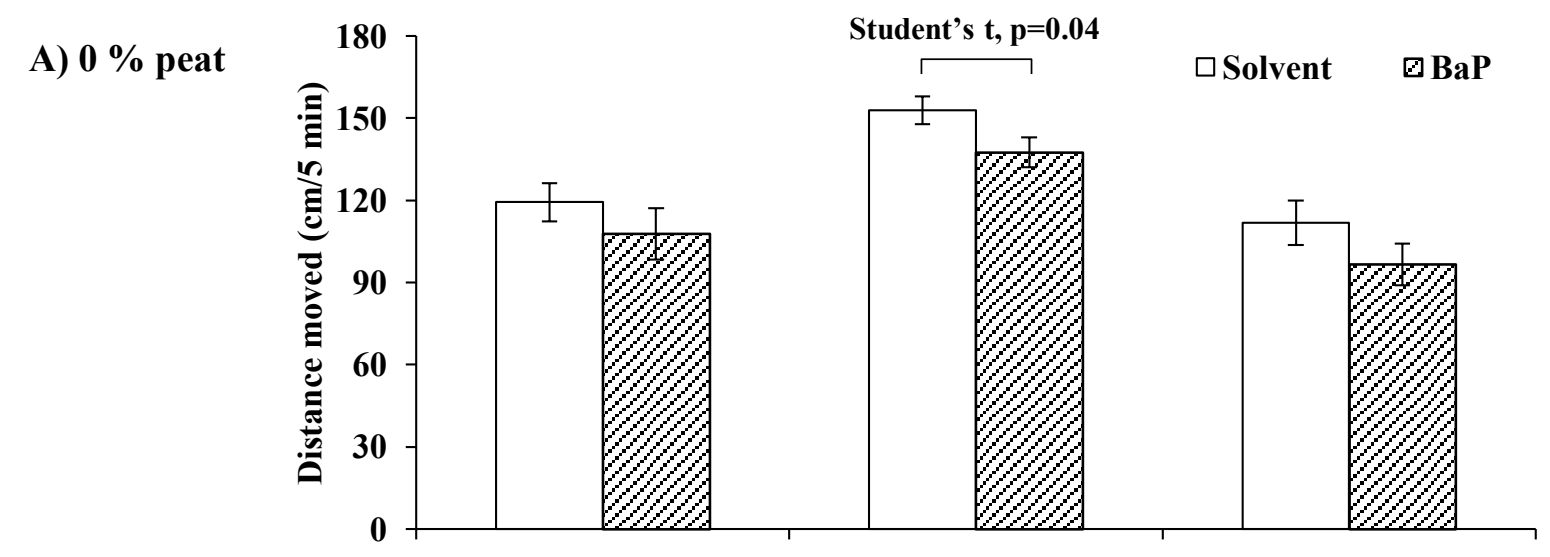

B) $2.5 \%$ peat

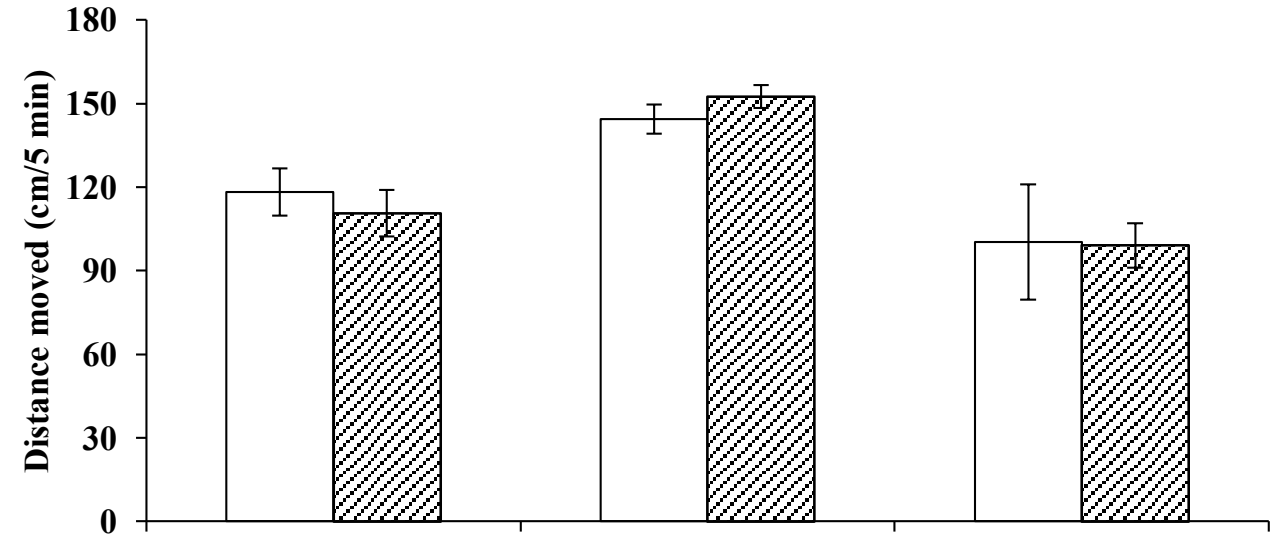

C) $5 \%$ peat

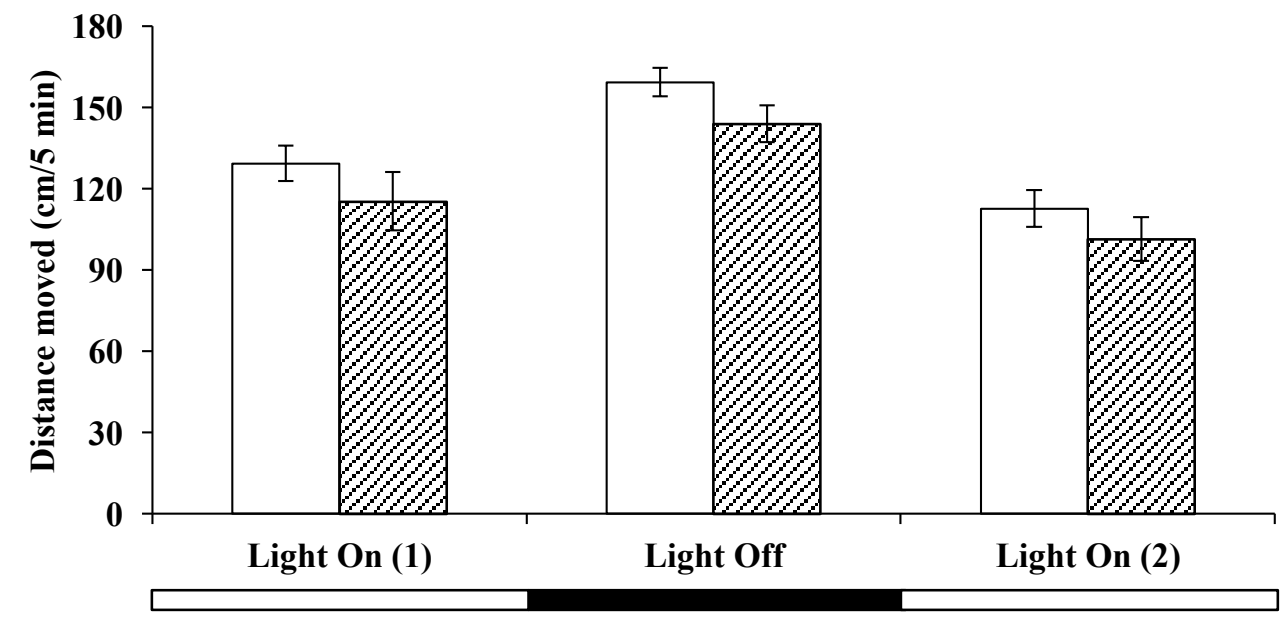


Figure 3

A) $0 \%$ peat

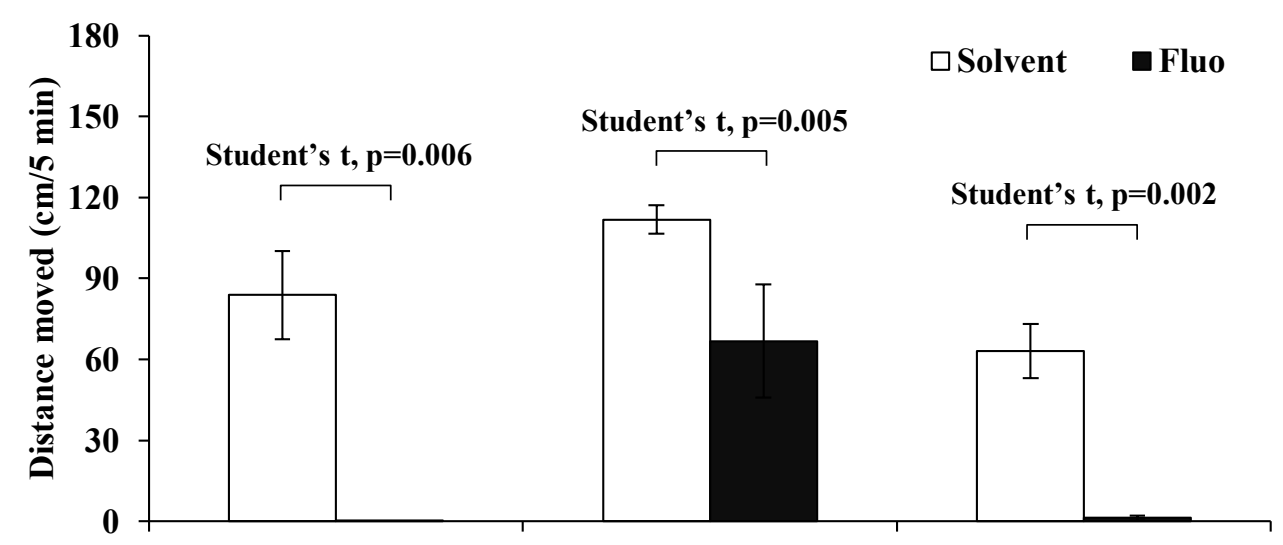

B) $2.5 \%$ peat

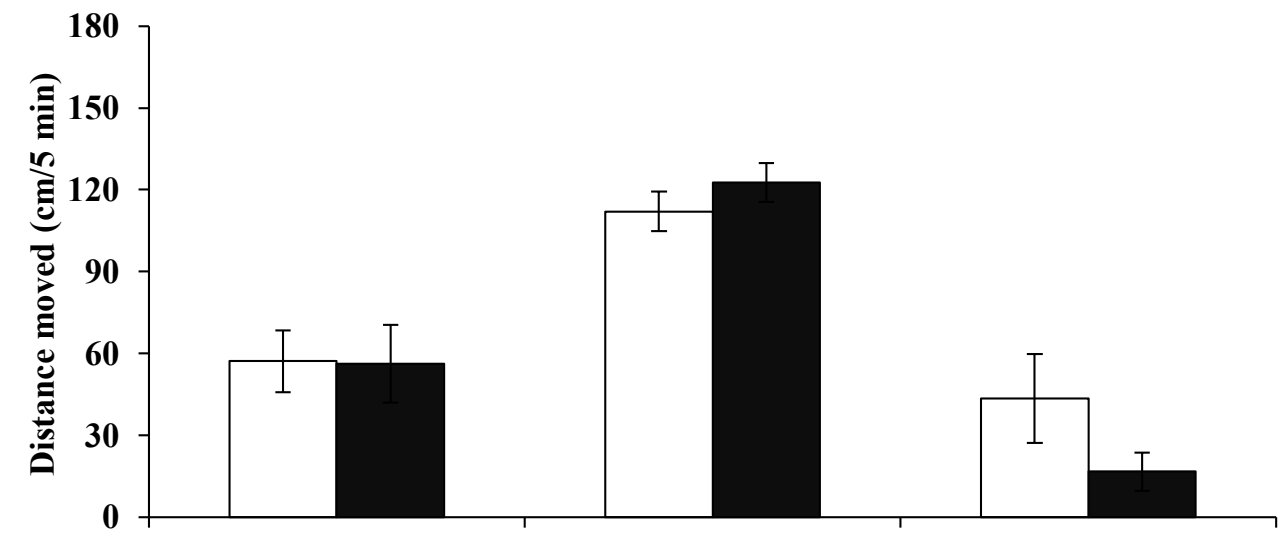

C) $5 \%$ peat

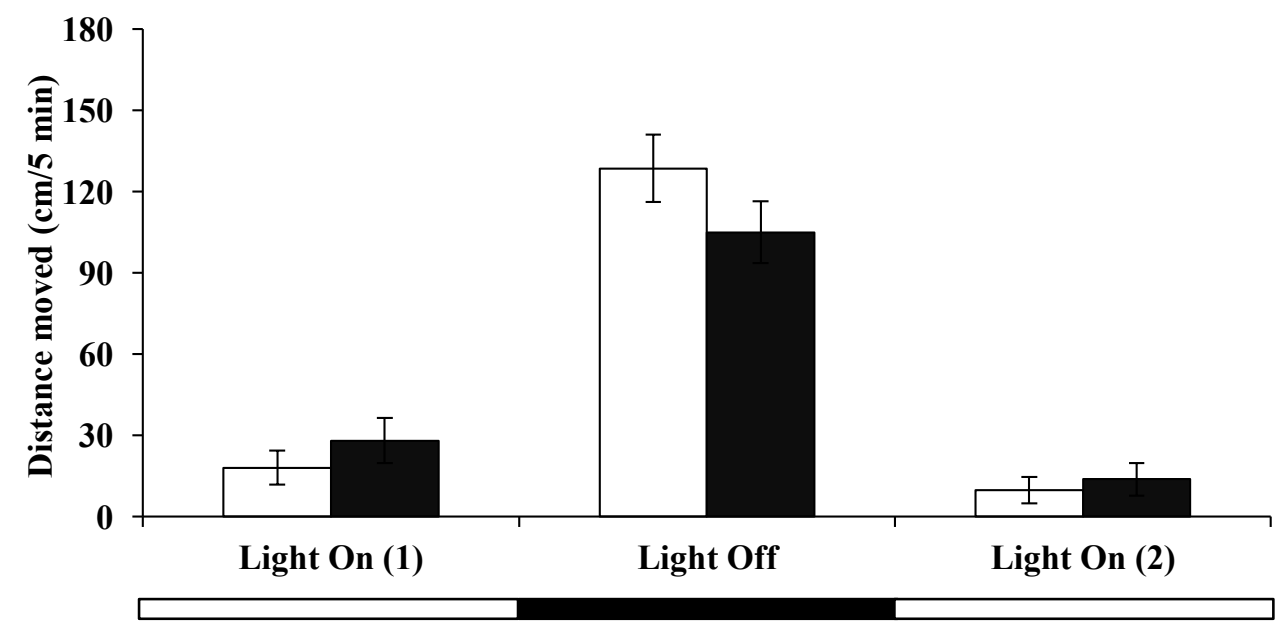


Figure 4

A) $0 \%$ peat

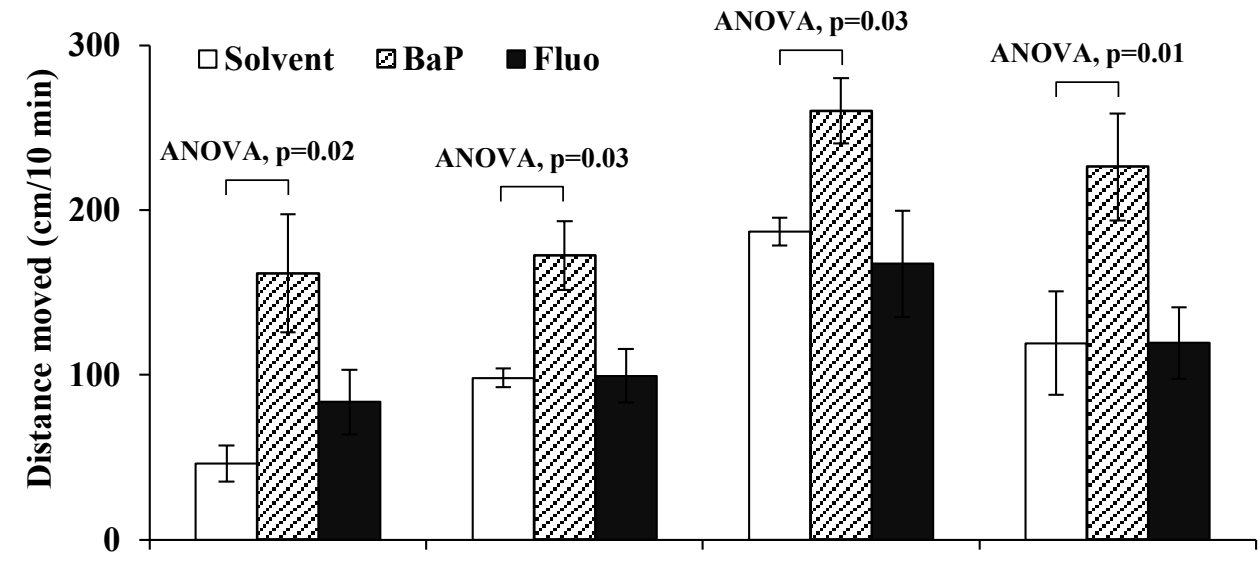

B) $2.5 \%$ peat

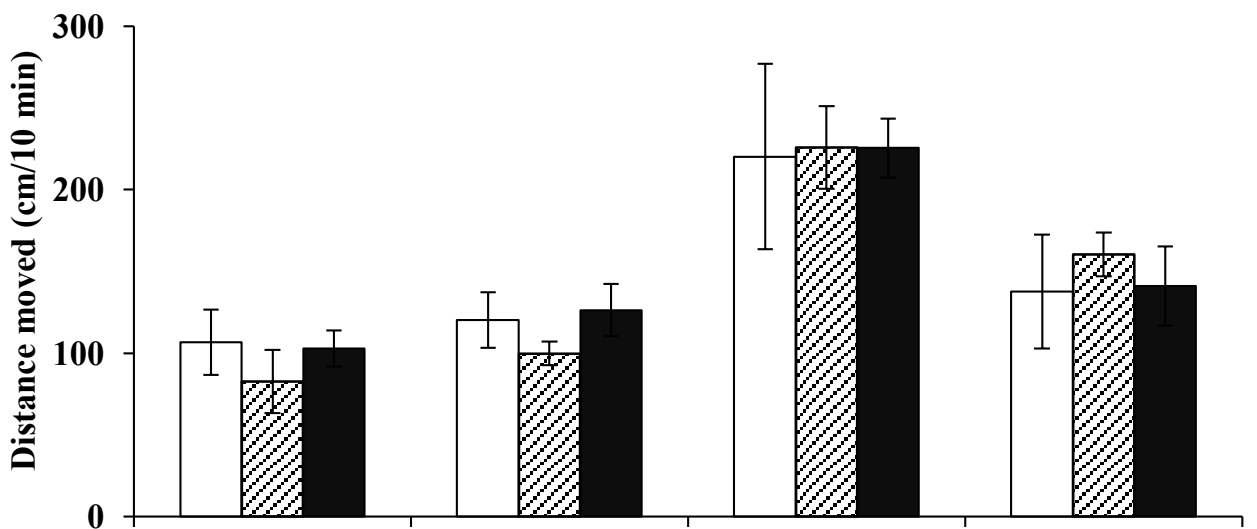

C) $5 \%$ peat

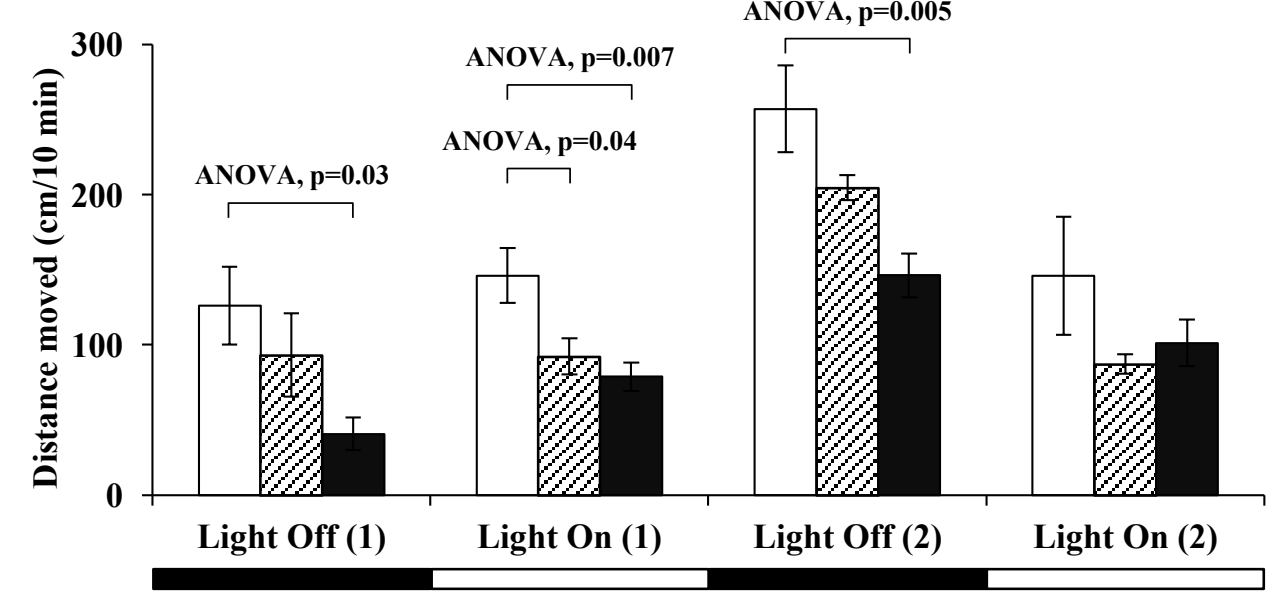


Table 1 Viability and hatching success of zebrafish assessing BaP and Fluo toxicity regarding different peat sediment contents

\begin{tabular}{|c|c|c|c|c|c|c|}
\hline & & & \multirow{2}{*}{$\begin{array}{c}\text { Measured concentration ng.g }{ }^{-1} \\
\text { dw (Spiking efficiency \%) }\end{array}$} & \multicolumn{2}{|c|}{ Survival rate $(\%)$} & \multirow{2}{*}{$\begin{array}{l}\text { Hatching success (\%) } \\
96 \mathrm{hpf}\end{array}$} \\
\hline & & & & $96 \mathrm{hpf}$ & $240 \mathrm{hpf}$ & \\
\hline \multirow{2}{*}{$0 \%$ Peat } & Solvent & $\mathrm{n}=89$ & & 89.9 & 89.9 & 100 \\
\hline & $\mathrm{BaP}$ & $\mathrm{n}=90$ & $1655(17)$ & 95.6 & 92.2 & 100 \\
\hline \multirow{2}{*}{$2,5 \%$ Peat } & Solvent & $\mathrm{n}=90$ & & 93.3 & 87.8 & 95.2 \\
\hline & $\mathrm{BaP}$ & $\mathrm{n}=90$ & $1736(18)$ & 94.4 & 92.2 & 100 \\
\hline \multirow{2}{*}{$5 \%$ Peat } & Solvent & $\mathrm{n}=90$ & & 93.3 & 88.9 & 100 \\
\hline & $\mathrm{BaP}$ & $\mathrm{n}=90$ & $1969(20)$ & 92.2 & 90.0 & 100 \\
\hline \multirow{2}{*}{$0 \%$ Peat } & Solvent & $\mathrm{n}=90$ & & 97.8 & 96.7 & 100 \\
\hline & Fluo & $\mathrm{n}=90$ & $6321(63)$ & $54.6^{*}$ & $46.6^{*}$ & $89.6^{*}$ \\
\hline \multirow{2}{*}{$2,5 \%$ Peat } & Solvent & $\mathrm{n}=90$ & & 95.6 & 93.3 & 100 \\
\hline & Fluo & $\mathrm{n}=90$ & $5912(59)$ & 96.7 & 96.7 & 96.5 \\
\hline \multirow{2}{*}{$5 \%$ Peat } & Solvent & $\mathrm{n}=90$ & & 96.7 & 94.4 & 97.7 \\
\hline & Fluo & $\mathrm{n}=90$ & $4396(44)$ & $83.5^{*}$ & $82.4^{*}$ & $84.2^{*}$ \\
\hline
\end{tabular}

Asterisks indicate significant differences with respective Solvent control (Homogenous triplicates, Fisher test, $p<0.05$ ) 
Table 2 Teratogenic effects on larval zebrafish exposed to $\mathrm{BaP}$ with different peat sediment contents

\begin{tabular}{|c|c|c|c|c|c|c|}
\hline & \multirow{2}{*}{\multicolumn{2}{|c|}{$0 \%$ peat }} & \multirow{2}{*}{\multicolumn{2}{|c|}{$2.5 \%$ peat }} & \multirow{2}{*}{\multicolumn{2}{|c|}{$5 \%$ peat }} \\
\hline & & & & & & \\
\hline & Solvent & $\mathrm{BaP}$ & Solvent & $\mathrm{BaP}$ & Solvent & $\mathrm{BaP}$ \\
\hline & $n=3$ & $n=3$ & $\mathrm{n}=3$ & $\mathrm{n}=3$ & $n=3$ & $\mathrm{n}=3$ \\
\hline Standard length (mm) & $3.57 \pm 0.03$ & $3.57 \pm 0.03$ & $3.58 \pm 0.03$ & $3.62 \pm 0.02$ & $3.60 \pm 0.03$ & $3.60 \pm 0.02$ \\
\hline Ratio Head/Standard length (\%) & $18.3 \pm 0.11$ & $18.6 \pm 0.14$ & $18.6 \pm 0.15$ & $18.2 \pm 0.18$ & $18.6 \pm 0.14$ & $18.5 \pm 0.11$ \\
\hline Yolk sac area $\left(\mathrm{mm}^{2}\right)$ & $0.33 \pm 0.01$ & $0.32 \pm 0.01$ & $0.34 \pm 0.01$ & $0.33 \pm 0.01$ & $0.35 \pm 0.01$ & $0.34 \pm 0.01$ \\
\hline Ratio Yolk sac/Whole larval area (\%) & $26.4 \pm 0.41$ & $26.4 \pm 0.53$ & $26.6 \pm 0.42$ & $25.5 \pm 0.37$ & $26.6 \pm 0.68$ & $26.4 \pm 0.48$ \\
\hline Abnormal individuals (\%) & 2.86 & 7.89 & 14.29 & 10.00 & 7.69 & 5.26 \\
\hline \multicolumn{7}{|l|}{ Severity of abnormality (scoring/3) $(\%)$ : } \\
\hline No affected (score 0$)$ & 97.14 & 92.11 & 85.71 & 90.00 & 92.31 & 94.74 \\
\hline Mild (score 1) & 0.00 & 2.63 & 2.86 & 7.50 & 0.00 & 0.00 \\
\hline Moderate (score 2) & 0.00 & 2.63 & 2.86 & 0.00 & 0.00 & 0.00 \\
\hline Severe (score 3 or more) & 2.86 & 2.63 & 8.57 & 2.50 & 7.69 & 5.26 \\
\hline \multicolumn{7}{|c|}{ Abnormalities among abnormal individuals (\%): } \\
\hline Oedemas & 1.43 & 2.63 & 5.10 & 3.33 & 3.21 & 1.50 \\
\hline Axial skeleton & 0.00 & 1.32 & 4.08 & 5.00 & 1.92 & 1.50 \\
\hline Craniofacial & 0.71 & 1.32 & 4.08 & 1.67 & 2.56 & 1.50 \\
\hline Cardiovascular & 0.00 & 0.00 & 0.00 & 0.00 & 0.00 & 0.00 \\
\hline Yolk sac malabsorption & 0.71 & 2.63 & 1.02 & 0.00 & 0.00 & 0.75 \\
\hline Developmental retardation $(\%)$ & 0.00 & 0.00 & 0.00 & 0.00 & 0.00 & 0.00 \\
\hline
\end{tabular}

No significant differences were observed (homogenous triplicates, $t$-test, $\mathrm{p}>0.05$ ) 
Table 3 Teratogenic effects on larval zebrafish exposed to Fluo with different peat sediment contents

\begin{tabular}{|c|c|c|c|c|c|c|}
\hline & \multirow{2}{*}{\multicolumn{2}{|c|}{$0 \%$ peat }} & \multirow{2}{*}{\multicolumn{2}{|c|}{$2.5 \%$ peat }} & \multirow{2}{*}{\multicolumn{2}{|c|}{$5 \%$ peat }} \\
\hline & & & & & & \\
\hline & Solvent & Fluo & Solvent & Fluo & Solvent & Fluo \\
\hline & $\mathrm{n}=3$ & $\mathrm{n}=3$ & $\mathrm{n}=3$ & $\mathrm{n}=3$ & $\mathrm{n}=3$ & $\mathrm{n}=3$ \\
\hline Standard length $(\mathrm{mm})$ & $3.45 \pm 0.02$ & $3.11 \pm 0.09 *$ & $3.41 \pm 0.02$ & $3.40 \pm 0.02$ & $3.30 \pm 0.02$ & $3.17 \pm 0.02 *$ \\
\hline Ratio Head/Standard length (\%) & $18.3 \pm 0.10$ & $16.4 \pm 0.42 *$ & $17.7 \pm 0.16$ & $17.2 \pm 0.20$ & $17.0 \pm 0.16$ & $17.3 \pm 0.20$ \\
\hline Yolk sac area $\left(\mathrm{mm}^{2}\right)$ & $0.31 \pm 0.01$ & $0.40 \pm 0.02 *$ & $0.31 \pm 0.01$ & $0.32 \pm 0.01$ & $0.33 \pm 0.01$ & $0.35 \pm 0.01$ \\
\hline Ratio Yolk sac/Whole larval area (\%) & $27.0 \pm 0.40$ & $39.0 \pm 2.50 *$ & $27.0 \pm 0.40$ & $28.0 \pm 0.50^{*}$ & $30.0 \pm 0.80$ & $32.0 \pm 0.90^{*}$ \\
\hline Abnormal individuals $(\%)$ & 4.65 & 22.22 & 7.32 & 2.56 & 2.44 & 10.53 \\
\hline \multicolumn{7}{|l|}{ Severity of abnormality (scoring/3) $(\%)$ : } \\
\hline No affected (score 0 ) & 95.35 & 77.78 & 92.68 & 97.44 & 95.12 & 78.95 \\
\hline Mild (score 1) & 2.33 & 11.11 & 7.32 & 2.56 & 2.44 & 15.79 \\
\hline Moderate (score 2) & 0.00 & 11.11 & 0.00 & 0.00 & 2.44 & 5.26 \\
\hline Severe (score 3 or more) & 2.33 & 0.00 & 0.00 & 0.00 & 0.00 & 0.00 \\
\hline \multicolumn{7}{|c|}{ Abnormalities among abnormal individuals (\%): } \\
\hline Oedemas & 1.16 & 11.11 & 7.32 & 2.56 & 0.00 & 3.51 \\
\hline Axial skeleton & 1.16 & 7.41 & 0.00 & 0.00 & 2.44 & 3.51 \\
\hline Craniofacial & 1.16 & 0.00 & 0.00 & 0.00 & 0.00 & 3.51 \\
\hline Cardiovascular & 0.00 & 0.00 & 0.00 & 0.00 & 0.00 & 0.00 \\
\hline Yolk sac malabsorption & 1.16 & 3.70 & 0.00 & 0.00 & 0.00 & 0.00 \\
\hline Developmental retardation (\%) & 2.0 & $56.0^{*}$ & 0.0 & 10.0 & 49.0 & $100.0 *$ \\
\hline
\end{tabular}

Asterisks indicate significant differences with respective solvent control (homogenous triplicates, $\mathrm{t}$-test, $\mathrm{p}<0.05$ ) 
Table 4 Comparison of BaP toxicity to zebrafish and Japanese medaka (Le Bihanic et al., 2014) early life stages for different peat concentrations in artificial sediment

\begin{tabular}{|c|c|c|c|c|c|c|c|}
\hline & \multirow{4}{*}{$\begin{array}{l} \\
\text { Exposure time } \\
\text { Peat concentration }\end{array}$} & \multirow{2}{*}{\multicolumn{3}{|c|}{ zebrafish }} & & & \\
\hline & & & & & \multicolumn{3}{|c|}{ Japanese medaka } \\
\hline & & \multicolumn{3}{|c|}{$96 \mathrm{hpf}$} & \multicolumn{3}{|c|}{$12 \mathrm{dpf}$} \\
\hline & & $0 \%$ & $2.5 \%$ & $5 \%$ & $0 \%$ & $2.5 \%$ & $5 \%$ \\
\hline \multirow{3}{*}{ Survival/Hatching } & Embryo-larval mortality & No & No & No & No & No & No \\
\hline & Hatching success & No & No & No & No & No & No \\
\hline & Hatching time & No & No & No & No & Yes $(+)$ & No \\
\hline \multirow{3}{*}{ Morphology } & Larval body length & No & No & No & No & No & No \\
\hline & Yolk sac area & No & No & No & No & Yes (-) & No \\
\hline & Abnormal individuals & No & No & No & No & No & No \\
\hline Behavior & Photomotor response & Yes (-) & No & No & Yes $(+)$ & No & No \\
\hline
\end{tabular}

Signs in brackets indicate significant inductor/increase (+) or inhibitor/decrease (-) effect compared to the solvent control respective 
Table 5 Comparison of Fluo toxicity to zebrafish and Japanese medaka (Le Bihanic et al., 2014) early life stages for different peat concentrations in artificial sediment

\begin{tabular}{|c|c|c|c|c|c|c|c|}
\hline & \multirow{4}{*}{$\begin{array}{l} \\
\text { Exposure time } \\
\text { Peat concentration }\end{array}$} & \\
\hline & & \multicolumn{3}{|c|}{ zebrafish } & \multicolumn{3}{|c|}{ Japanese medaka } \\
\hline & & \multicolumn{3}{|c|}{$96 \mathrm{hpf}$} & \multicolumn{3}{|c|}{$12 \mathrm{dpf}$} \\
\hline & & $0 \%$ & $2.5 \%$ & $5 \%$ & $0 \%$ & $2.5 \%$ & $5 \%$ \\
\hline \multirow{3}{*}{ Survival/Hatching } & Embryo-larval mortality & Yes $(+)$ & No & Yes $(+)$ & No & No & No \\
\hline & Hatching success & Yes (-) & No & Yes (-) & No & No & No \\
\hline & Hatching time & No & No & No & No & Yes $(+)$ & No \\
\hline \multirow{3}{*}{ Morphology } & Larval body length & Yes $(-)$ & No & Yes (-) & No & No & No \\
\hline & Yolk sac area & Yes $(+)$ & No & No & No & Yes (-) & No \\
\hline & Abnormal individuals & No & No & No & Yes $(+)$ & Yes $(+)$ & Yes $(+)$ \\
\hline Behavior & Photomotor response & Yes (-) & No & No & No & No & Yes (-) \\
\hline
\end{tabular}

Signs in brackets indicate significant inductor/increase $(+)$ or inhibitor/decrease $(-)$ effect compared to the solvent control respective 